\title{
Towards a Sustainable Electricity Supply in Nigeria: The Role of Decentralized Renewable Energy System
}

\author{
Sunday Olayinka Oyedepo 1*, Olufemi P. Babalola 1, Stephen C. Nwanya 2, Oluwaseun Kilanko 1, \\ Richard O. Leramo ${ }^{1}$, Abraham K. Aworinde ${ }^{1}$, Tunde Adekeye ${ }^{1}$, Joseph A. Oyebanji ${ }^{3}$, \\ Abiodun O. Abidakun ${ }^{4}$, Orobome Larry Agberegha ${ }^{5}$
}

\author{
${ }^{1}$ Covenant University, Km 10 Idiroko Rd, Ota, Nigeria, 112233 Ota, NIGERIA \\ ${ }^{2}$ University of Nigeria, Nsukka, NIGERIA \\ ${ }^{3}$ Bells University of Technology, Ota, NIGERIA \\ ${ }^{4}$ West Virginia University, Evansdale Campus, Morgantown, WV, 26506, USA \\ ${ }^{5}$ Federal University of Petroleum Resources, Effurun, NIGERIA
}

*Corresponding Author: sunday.oyedepo@covenantuniversity.edu.ng

Citation: Oyedepo, S. O., Babalola, O. P., Nwanya, S. C., Kilanko, O., Leramo, R. O., Aworinde, A. K., Adekeye, T., Oyebanji. J. A., Abidakun, A. O. and Agberegha, O. L. (2018). Towards a Sustainable Electricity Supply in Nigeria: The Role of Decentralized Renewable Energy System. European Journal of Sustainable Development Research, 2(4), 40. https://doi.org/10.20897/ ejosdr/3908

Published: October 4, 2018

\begin{abstract}
In Nigeria, access to reliable and stable supply of electricity is a major challenge for both the urban and rural dwellers. In this study, comprehensive review of accessibility to clean and modern energy in Nigeria has been carried out. Also, this paper examines the potential of renewable energy (RE) resources in Nigeria that can be harnessed for continuous energy supply and the government's efforts to ensure RE's sustainability. Nigeria is endowed with abundant energy resources but the existing electric energy infrastructures are unable to meet the energy demands of teeming population. There is imbalance in energy supply and demand in the country. Over the period from 2000 to 2014, there was an average of about 2.35 billion $\mathrm{kWh}$ of energy gap between energy production and energy consumption. The highest electricity consumption per capita recorded so far was $156 \mathrm{kWh}$ in 2012. This makes Nigeria one of the country with the lowest electricity consumption on per capita basis in the world. In order to improve access to clean energy supply and achieve sustainable development, this paper pin points the significance of decentralized renewable energy systems and needs for the government to review the policies on renewable energy development in the country.
\end{abstract}

Keywords: energy infrastructures, decentralized energy system, renewable energy technologies, modern energy, poverty reduction, sustainable development

\section{INTRODUCTION}

During the last few years the 'energy issue' has been assuming a more and more important role among any other choice, strategy and policy concerning human survival and development. Modern societies strongly depend on reliable, affordable and sustainable energy supplies. In fact, energy is an obligatory input for most production processes and other economic activities and an essential component of way of life. Increased access to modern energy services is vital for social and economic development (Oyedepo, 2014a).

At present, majority of energy resources in the world are derived from fossil fuels (such as natural gas, oil and coal) which inevitably leads to the continuing depletion of energy resources and leading to adverse environmental 
impacts. Many people are concerned about these problems and wish to address the symptoms as a matter of urgency, but not all understand the basic causes and consequently do not realize that not only technological, but also social changes are required. It is now widely acknowledged that renewable energy capacity has to be increased by exploiting its enormous potential (Lorenzini et al., 2010). Hence, development and deployment of clean, renewable energy is imperative in the economic and environmental interest for every country.

Renewable energy has an important role to play in meeting future energy needs and achieving sustainability. However, its diffusion and deployment is slow in the past decade due to low fossil fuel prices and barriers in the energy market. Rigorous methods are needed to accelerate the development and utilization of renewable energy, and to increase its contribution to the current energy supply mixes (Nnaji et al., 2010).

The need for developing countries to enhance their renewable energy applications will present economic opportunities for trading-based cities. The use of renewable energy in developing countries like Nigeria is at present very limited, although their potential is believed to be significant (Oyedepo, 2012a).

Due to various financial and technical constraints, renewable energy remains untapped in Nigeria. Nigeria continues to be heavily dependent on fossil fuels. The detrimental impacts on the environment and, the financial burden placed on the economy, through the current inefficient use of these fossil fuels, need to be addressed through the application of appropriate technologies, national energy policies and management measures. Nonetheless, the social and economic development and poverty alleviation are the overriding priorities of Nigeria. The energy requirements for the urgently needed socioeconomic development in this country could be provided by renewable energy (RE) sources. Thus, in order to promote renewable energy technologies (RETs) in Nigeria, more effective and responsive policies are required that would cater for immediate needs of people.

A country experiencing energy poverty can be said to be a situation where its citizens lack electric power to meet even their basic needs such as lighting and cooking. In this situation, a large number of people in the developing countries like Nigeria are negatively affected by their very low consumption of energy use, while some use dirty polluting fuels and others spend excessive time to obtain fuel in order to meet their basic needs (Emodi and Boo, 2015). According to the Energy Poverty Action Initiative of the World Economic Forum (IEA, 2007), "Access to energy is fundamental to improve the quality of life and is a key imperative for economic development."

Poor access to energy in Nigeria obviously translates into increased poverty, poor economic performance, limited employment opportunity and complicated prospects for institutional development. The high growth rate of the population is an indication that the country's energy demand will continue to rise, similar to how the increase in global population and industrial transformation of the $20^{\text {th }}$ century tremendously increased energy demand (Mohammeda, 2013). The energy crisis situation in Nigeria has considerably affected the public users of electricity. This phenomenon has undeniably compelled the majority of households in both rural and urban segments of the country to significantly depend on combustible RE sources especially for domestic heating and cooking. Fuel wood and charcoal are widespread energy sources commonly used in Nigeria. Universally accessible energy services in the form of renewable energy resources that are adequate, affordable, reliable, of good quality, safe and environmentally benign are therefore a necessary condition for sustainable development and poverty reduction in the country.

The prime objectives of this study are to: (i) review energy resources in Nigeria and present status of power sector (ii) review the potentials and utilization of renewable energy sources (solar, wind, small hydro and biomass) in Nigeria (iii) review factors mitigating against development of renewable energy technologies in Nigeria (iv) to assess the roles of decentralized renewable energy systems as means of achieving sustainable energy in Nigeria.

\section{THE NIGERIAN ENERGY SCENARIO}

\section{An Overview of Power Sector in Nigeria}

Electricity as an essential commodity for modern people is very important for the future development of the society. This good must be supplied on a continuous basis in order to cover the daily requirements. To this end, the performance and efficiency of power generation industry (Power Sector) is of great importance towards achieving quality and reliable supply of electricity. Continuous access to quality energy infrastructure is an essential ingredient for sustained economic growth and development. Inadequate supply of electricity has the capability to retard development of industries, small scale businesses, hospitals and establishment of other infrastructural facilities in the urban and rural settlements (Oyedepo et al., 2012).

Power Sector is a basic constituent for the development of worldwide economy; its evolution is based on making quality compatible with energy service, as it is the only means to lay the foundation of a stable sharp and economic growth. According to the Ministry of Economy (2002), the Power sector constitutes an essential part of the economic activity of a country being a dynamic element of the same, as well as, it supposes an undeniable 
strategic value to the rest of the sectors of the economy. For that reason, the power provision in optimal conditions of security, quality and price is not to be waived objective in the definition of the power policy of a country.

One of the ways of meeting the growing energy demand in a developing country like Nigeria is to have a suitable and sustainable means of power generation. Unfortunately, Nigeria's power sector has been experiencing enormous challenges due to obsolete equipment, inadequate generation and transmission capacities, and, high aggregate technical and commercial losses. These challenges stem from decades of neglect, mismanagement and inadequate funding. The problems worsened as a result of massive increase in demand of electricity due to economic and population growth.

The grid power is unreliable and insufficient to meet growing demand, resulting in frequent load-shedding and other outages. This has as well limited majority of Nigerians' access to clean and modern energy services. Moreover, the epileptic nature of the country's electricity supply has resulted to a widespread self-generation of power from alternative sources in Nigeria: the rich rely heavily on generators which caused the use of petroleum products to increase by 75\% in 2012 (Udoudoh and Umoren, 2015).

Lack of electricity has forced about $62 \%$ of Nigerians to rely on wood fuel for their entire energy needs resulting in massive deforestation in the country (Babanyara and Saleh, 2010; Eleri et al, 2012; Zubairu et al., 2015). The dependence on firewood has also constitutes a major indoor pollution hazard and has caused the death of about 79,000 Nigerians due to smoke inhalation in 2011 (Eleri and Onuvae, 2011). According to a study by the World Health Organization in 2013, the death caused by smoke inhalation from fire wood used by women reached 98,000 (Emodi and Boo, 2015).

Over the last decade, the Nigerian power sector sought for the best possible way forward towards improving power availability in the country. In 2005, the federal government launched a series of large - scale initiatives for the power transformation. The National Electric Power Authority (NEPA), the sole provider of electricity, was replaced by the Power Holding Company of Nigeria (PHCN), which was unbundled into 6 generation companies (GenCos), 11 distribution companies (DisCos) and the Transmission Company of Nigeria (TCN) (Wijeratne and Omontuemhen, 2016). With the passing into law of the Electric Power Sector Reform Act by the National assembly in 2005, the Nigerian electricity Regulatory Commission (NERC) was inaugurated on the 1st of November 2005, with the sole responsibility to regulate activities in the power sector including tariff regimes (Okafor, 2017). Other independent body, the Rural Electrification Agency (REA) was formed to oversee progress and maintain transparency in the power sector. Along the way, initiatives were launched to diversify the power sector through agreements to invest in hydropower, nuclear power and a range of renewable power sources. In 2010, a Roadmap for Power Sector Reform was developed, which privatised the generation and distribution companies, while transmission of electricity remained state-owned. In addition, the Nigeria Bulk Electricity Trading Plc (NBET) was formed to 'engage in the purchase and resale of electric power and ancillary services from independent power producers and from the successor generation companies (Idemudia and Nordstrom, 2016). Figure 1 summarizes the current key players in Nigeria's reformed power sector.

The fundamental objective of the power sector reform is to ensure that Nigeria has an electricity supply industry that can meet the needs of the citizens in the twenty - first century. Others are to modernize and expand electricity coverage and support national, economic and social development (ECN, 2014). Unfortunately, despite public and private sectors commitment to improving the power eco-system through investment, increased competitiveness and deregulation since the reform process started in 2010 and until date, there appears not to be any significant improvement in the power sector and the core issue of lack of power remain unresolved with very little hope in sight while prices keep increasing. There is still a long way to go before Nigeria's power infrastructure capabilities will be on a par with other emerging economies. The immediate focus needs to be towards removing or at least reducing the key barriers to generating, transmitting and distributing power nationwide.

\section{Current Electricity Generation and Consumption in Nigeria}

There are currently 27 grid connected generating power stations in the Nigeria Electricity Supply Industry (NESI). The installed capacity as of 23th of February 2017 was 7102 MW and generation capability was 6882.8MW. The peak generation to date is 4602.4 MW with peak energy of 109,372.01 MWH (Okafor, 2017; Sambo, 2018). Generation is mostly thermal based ( $81 \%$ of installed capacity). Hydropower from three major plants account for $1,938 \mathrm{MW}$ of total installed capacity from an available capacity of $1,060 \mathrm{MW}$. The plants run by generation companies include those formerly under PHCN, NIPPs, and the Independent Power Producers (United Capital, 2017).

The existing fleet of power plants in Nigeria is a mix of plants built before the 1990's and plants built (or being built) since the mid-1990's (Table 1). The poor performance of the power plants has led to acute shortage of electricity across the country with power outages of several hours per day (Adegbulugbe, 2007). Generating plant 


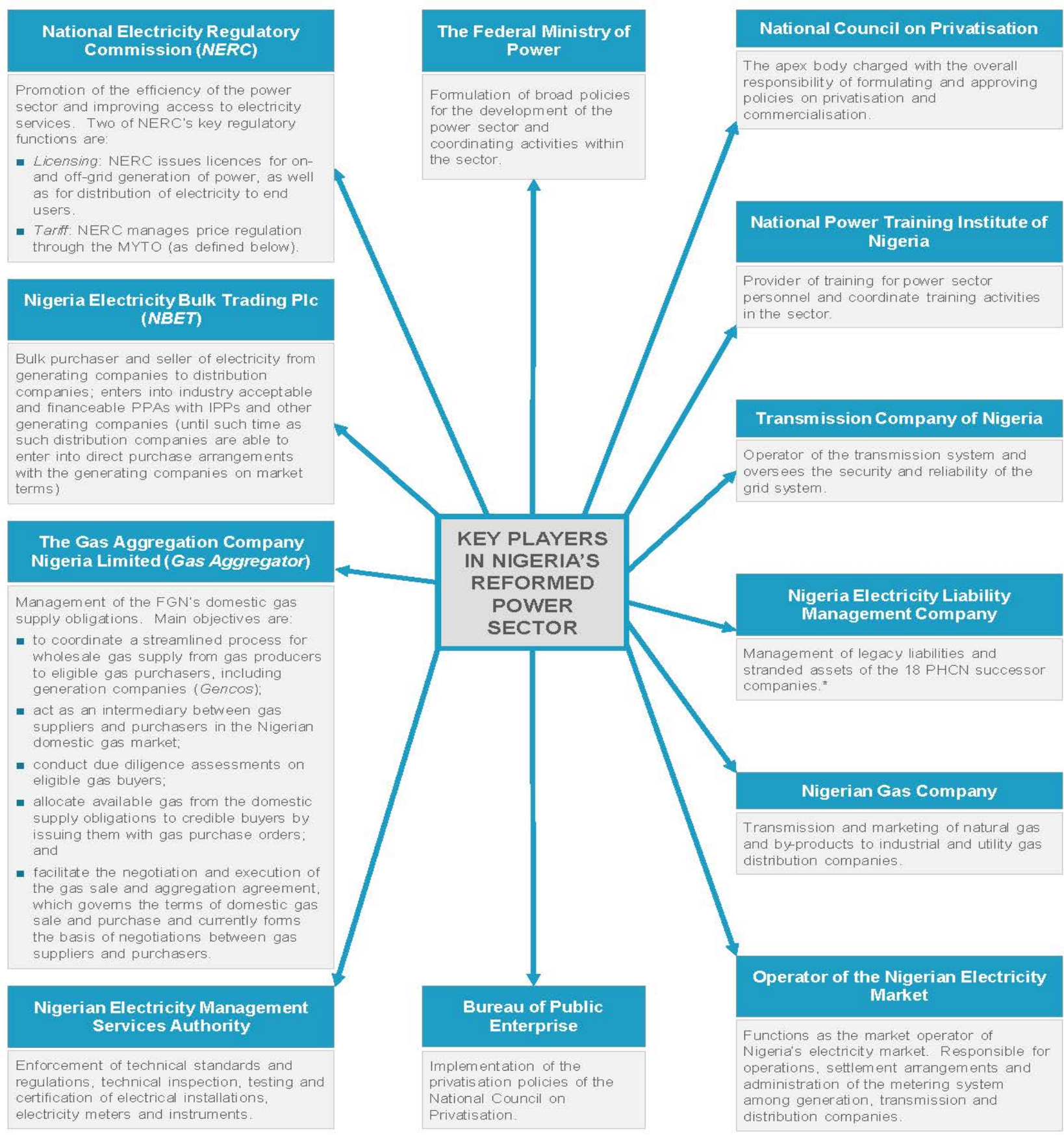

Figure 1. The current key players in Nigeria's reformed power sector. Source: Idemudia and Nordstrom (2016)

availability is low and the demand - supply gap is crippling. Poor services have forced most industrial customers to install their own power generators, at high costs to themselves and the Nigerian economy (Oyedepo, 2014b).

Inadequate transmission infrastructure is among the constraints the on-grid power generation has over the years. The Nigerian Electricity Transmission system consist of about 5,523.8 km of $330 \mathrm{KV}$ lines and 6,801.49 km of $132 \mathrm{KV}$ lines, 6,098MVA transformer capacity at $330 / 132 \mathrm{kV}$ and $8,090 \mathrm{MVA}$ transformer capacity at $132 / 33 \mathrm{kV}$ (Okafor, 2017). The wheeling capacity of Transmission Company of Nigeria (TCN) is 5,500MW while the distribution capacity is about $6 \mathrm{GW}$ (Sambo, 2018). In the last three years, TCN has been able to achieve significant improvements in its operations, system reliability and efficiency. For example, incidences of system collapse have drastically reduced from 42 system collapses in 2010 to about six system collapses recorded in 2016 (Lawal and Ojo, 2017). Nonetheless, the system is operating well below international reliability and security standards. Frequency and voltage recordings often exceed established norms. The existing transmission system is weak and is majorly radial, which means that it's a single path of transmission with a power source at one end. This implies that any fault in the path could potentially lead to a collapse of the transmission network. The issue with transmission has been estimated to reduce the power generation capacity by a total of about $263 \mathrm{MW}$. Although, the Transmission Company of Nigeria plans to upgrade the transmission system to a capacity of $11,000 \mathrm{MW}$ by 
European Journal of Sustainable Development Research, 2(4), 40

Table 1. Existing Nigerian Power Plant Fleet Showing Peak Generation as at March 2018

\begin{tabular}{|c|c|c|c|c|c|}
\hline Power Station & Type & $\begin{array}{c}\text { Year } \\
\text { Completed }\end{array}$ & $\begin{array}{c}\text { Installed Capacity } \\
\text { (MW) }\end{array}$ & $\begin{array}{c}\text { Installed Available } \\
\text { Capacity (MW) }\end{array}$ & $\begin{array}{c}\text { Peak Gen. (MW) as } \\
\text { at March } 2018\end{array}$ \\
\hline $\mathrm{AES}$ & SCGT & 2001 & 270 & 267 & 0 \\
\hline Afam IV - V & SCGT & 1982 & 580 & 98 & 104 \\
\hline Afam VI & SCGT & 2009 & 980 & 559 & 281 \\
\hline Alaoji NIPP & CCGT & 2015 & 335 & 127 & 0 \\
\hline Delta & SCGT & 1990 & 740 & 453 & 507 \\
\hline Egbin & Gas Fired Steam Turbine & 1985 & 1320 & 931 & 478 \\
\hline Geregu & SCGT & 2007 & 414 & 282 & 71 \\
\hline Geregu NIPP & SCGT & 2012 & 434 & 424 & 100 \\
\hline Ibom Power & SCGT & 2009 & 142 & 115 & 82.1 \\
\hline Ihovbor NIPP & SCGT & 2012 & 450 & 327 & 107 \\
\hline Jebba & Hydro & 1986 & 570 & 427 & 412 \\
\hline Kainji & Hydro & 1968 & 760 & 180 & 384 \\
\hline Okpai & CCGT & 2005 & 480 & 424 & 195 \\
\hline Olorunsogo & SCGT & 2007 & 335 & 244 & 123 \\
\hline Olorunsogo NIPP & CCGT & 2012 & 675 & 356 & 0 \\
\hline Omoku & SCGT & 2005 & 150 & 0 & 78.4 \\
\hline Omotosho & SCGT & 2005 & 335 & 242 & 168.1 \\
\hline Omotosho NIPP & SCGT & 2012 & 450 & 318 & 107.8 \\
\hline River IPP & SCGT & 2009 & 136 & 166 & 125 \\
\hline Sapele & Gas Fired Steam Turbine & 1978 & 900 & 145 & 55 \\
\hline Sapele NIPP & SCGT & 2012 & 450 & 205 & 212.2 \\
\hline Shiroro & Hydro & 1989 & 600 & 480 & 131 \\
\hline Odukpani & SCGT & 2013 & 600 & 400 & 392.4 \\
\hline$\overline{\mathrm{ASCO}}$ & SCGT & 2016 & 294 & 270 & 0 \\
\hline Trans Amadi NIPP & SCGT & 2017 & 150 & 100 & 41.3 \\
\hline Azura Edo IPP & SCGT & 2018 & 450 & 400 & 301 \\
\hline Gbarain NIPP & SCGT & 2017 & 225 & 200 & 74.4 \\
\hline Total & & & 13234 & 8140 & 4529.7 \\
\hline
\end{tabular}

Key: SCGT - Simple Cycle Gas Turbine, CCGT - Combined Cycle Gas Turbine. Source: NERC 2015, Sambo, 2018

2020 (subject to adequate funding and completion of projects planned for implementation); the transmission infrastructure in its current state, without an upgrade and improved technology, is unable to accommodate the estimated increase in generation by 2020 .

The Nigerian power sector is characterized by comparatively large technical losses of between 20 and 50 per cent from 1980 to 2000. According to defunct Power Holding Company for Nigeria (PHCN) data, 25.1 per cent of the energy sent out by power stations is lost in transmission and distribution. Some of these losses are due to unmetered and unbilled energy consumption; others are due to technical problems encountered as a result of the long distances between consumers and power stations. Ultimately, Nigeria loses on average at least one third of its energy by the time it reaches the end consumer (Oyedepo and Fagbenle, 2011).

The acute electricity supply hinders the country's development, notwithstanding the availability of vast natural resources in the country (Ajao, et al., 2009, www.nipc.gov.ng). Based on this fact, there is need for alternative renewable sources of fuel for our power plants for $100 \%$ supply cannot be over emphasized. The adoption of renewable energy technologies in a decentralized energy manner, especially for rural communities and in standalone applications, will improve electricity supply and enhance the overall economic development.

Figure 2 shows the historic development of electricity generation in Nigeria and of the selected peer countries. It is observed that Nigeria performed worst of the five countries in terms of absolute electricity generation. Over a 20 year period, there was an increase of $93 \%$ in mainline generating capacity in Nigeria. By contrast, Indonesia ramped up its electricity production by $372 \%$ and Bangladesh even by $451 \%$. As a result, Bangladesh generated almost twice as much electrical energy in 2012 as Nigeria did (Werner and Faruk, 2015).

Table 2 shows the comparative energy consumption of some selected countries. The country's electricity consumption per capita as at 2015 was $134 \mathrm{kWh}$ (Table 2) which is very low compared with most countries in the world like USA with 12,083 kWh, Germany 7,204 kWh, UK 4,740 kWh and China 4,039 kWh in the same year. At $134 \mathrm{kWh}$ per capita, Nigeria lags significantly behind other developing nations in terms of electricity consumption. Based on the country's current demographics and global trends, electricity consumption should be four to five times higher than $134 \mathrm{kWh}$. For instance, the global minimum average electricity consumption per capita for developing economies is $500 \mathrm{kWh}$, about 4 times Nigeria's. Ghana's per capita consumption stands at $403 \mathrm{kWh}$, about 3.0 times Nigeria, while South Africa with 4,363 kWh consumes over 30 times Nigeria's power. The rule of thumb is that an industrial nation requires 1,000 MW per million inhabitants. This would imply that 


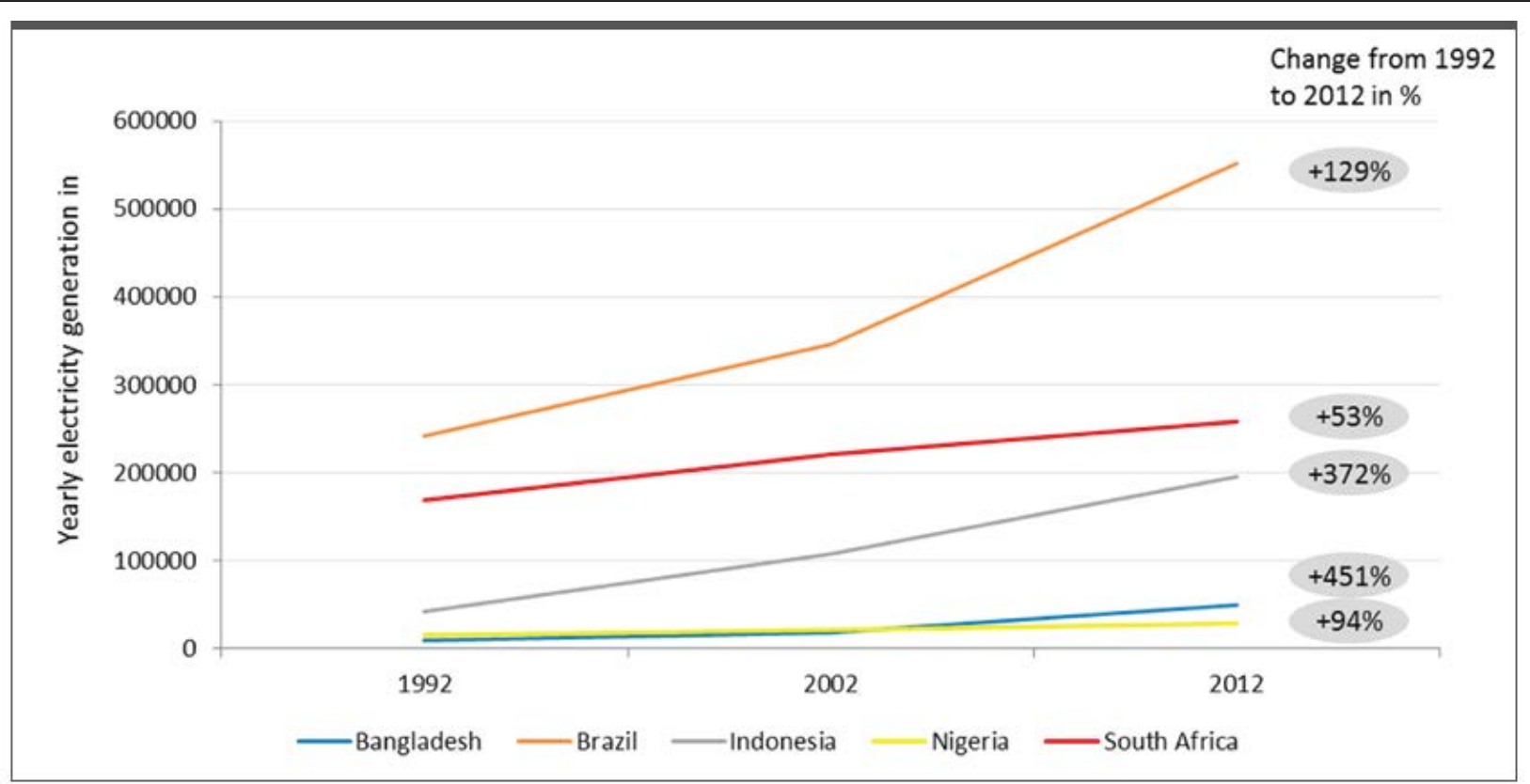

Figure 2. Electricity Generation (GWh) in Nigeria and Peer Countries since 1992. Source: IEA (2013)

Table 2. Comparative Energy Consumption of Some Selected Countries as at 2015

\begin{tabular}{llcccc}
\hline Country & $\begin{array}{l}\text { Population } \\
\text { (Million) }\end{array}$ & $\begin{array}{c}\text { Installed Generating } \\
\text { Capacity }(\mathbf{G W})\end{array}$ & $\begin{array}{c}\text { Generation } \\
\text { Capacity (GW) }\end{array}$ & $\begin{array}{c}\text { Energy Consumption } \\
\text { (billion kwh) }\end{array}$ & $\begin{array}{c}\text { Energy Consumption per } \\
\text { Capita (kwh) }\end{array}$ \\
\hline USA & $321,368,864$ & 1,074 & 1,053 & 3,883 & 12,083 \\
\hline Germany & $80,854,408$ & 204 & 178 & 583 & 7,204 \\
\hline UK & $64,088,222$ & 95 & 76 & 304 & 4,740 \\
\hline South Africa & $53,675,563$ & 47 & 44 & 234 & 4,363 \\
\hline China & $1,367,485,388$ & 1,646 & 1,505 & 5,523 & 2,039 \\
\hline Brazil & $204,259,812$ & 156 & 119 & 479 & 1,344 \\
\hline Egypt & $88,487,396$ & 39 & 27 & 129 & 602 \\
\hline Indonesia & $255,993,674$ & 53 & 41 & 156 & 605 \\
\hline India & $1,251,695,584$ & 309 & 223 & 758 & 403 \\
\hline Ghana & $26,327,649$ & 5 & 3.0 & 11 & $\mathbf{1 3 4}$ \\
\hline Nigeria & $\mathbf{1 7 2 , 5 6 2 , 0 5 6}$ & $\mathbf{1 0}$ & $\mathbf{7 . 6}$ & $\mathbf{2 3}$ & \\
\hline Sourc: Won
\end{tabular}

Source: World Factbook 2016

Nigeria requires $180,000 \mathrm{MW}$ for full power, which is a massive distance away from the federal government's target of 10,000MW by 2020 (Usman and Abbasoglu, 2015).

Electricity consumption per capita in Nigeria for the period $1971-2013$ is presented in Figure 3. The value varied from $29 \mathrm{kWh}$ to $156 \mathrm{kWh}$. The highest value ever recorded was $156 \mathrm{kWh}$ in 2012 (CIA, 2014). There was a drop in this value to $134 \mathrm{kWh}$ in 2015 . Nigeria is one of the country with the lowest electricity consumption on a per capita basis in the world. More than half of the nation's 176 million people are not connected to the national electricity grid. The country's paltry power generation, which is shamefully low, is expectedly inadequate for those connected to the grid (World Bank, 2014; Odhiambo, 2014).

According to Abam et al. (2014), the electric power generating sector in Nigeria is relatively small when compared with the teeming population and consequent energy consumption. The overall electricity production and consumption from 2000 to 2014 are presented in Figure 4. The electricity production increased from 14.75 billion $\mathrm{kWh}$ in 2000 to 24.87 billion $\mathrm{kWh}$ in 2014 while consumption increased from 13.72 billion $\mathrm{kWh}$ in 2000 to 20.38 billion $\mathrm{kWh}$ in 2014. From Figure 4, it can be seen that electric power production and electric power consumption in Nigeria have generally followed the same trend over the period of 2000 - 2014. In the exception of some rare instances, increases in electric power production have been associated with increases in electric power consumption and vice versa. For example, when electricity production increased from 14.75 billion $\mathrm{kWh}$ in 2000 to 18.70 billion $\mathrm{kWh}$ in 2001 , electricity consumption also increased from 13.72 billion $\mathrm{kWh}$ to 17.37 billion $\mathrm{kWh}$ over the same period. Besides, a sudden drop in electricity production from 18.70 billion $\mathrm{kWh}$ in 2001 to 15.67 billion kWh in 2004 forced electricity consumption to decline from 17.37 billion $\mathrm{kWh}$ to 14.55 billion kWh during this period. The difference between electricity production and consumption has averaged about 2.35 billion $\mathrm{kWh}$ for the period considered. This indicates that about 2.35 billion $\mathrm{kWh}$ of the electric power generated has mostly not been consumed. The effects of the wide gap between electricity production and consumption in the country 


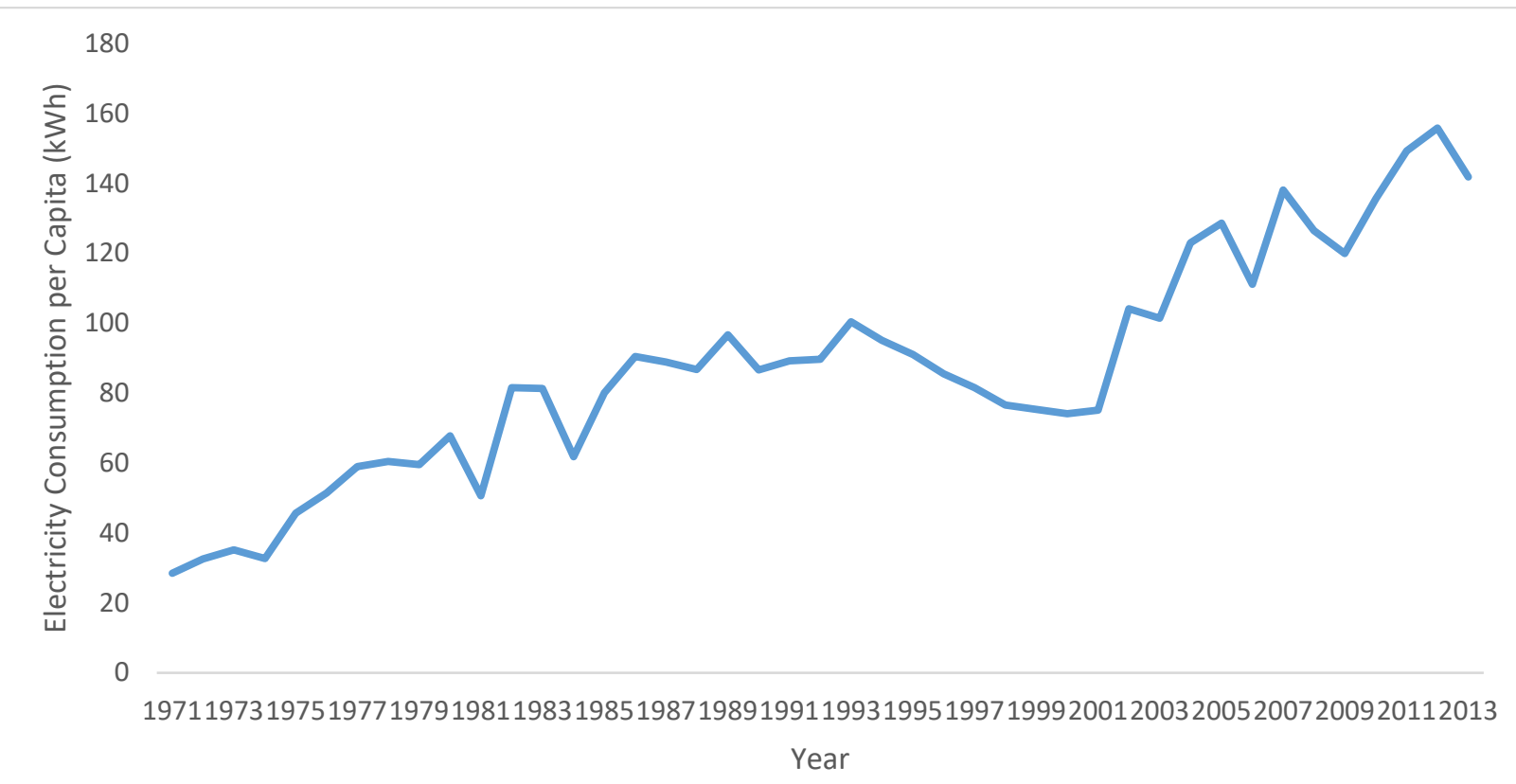

Figure 3. Electricity consumption per capita (kWh) from 1971-2013. Source: Constructed from the CIA World Factbook (2014).

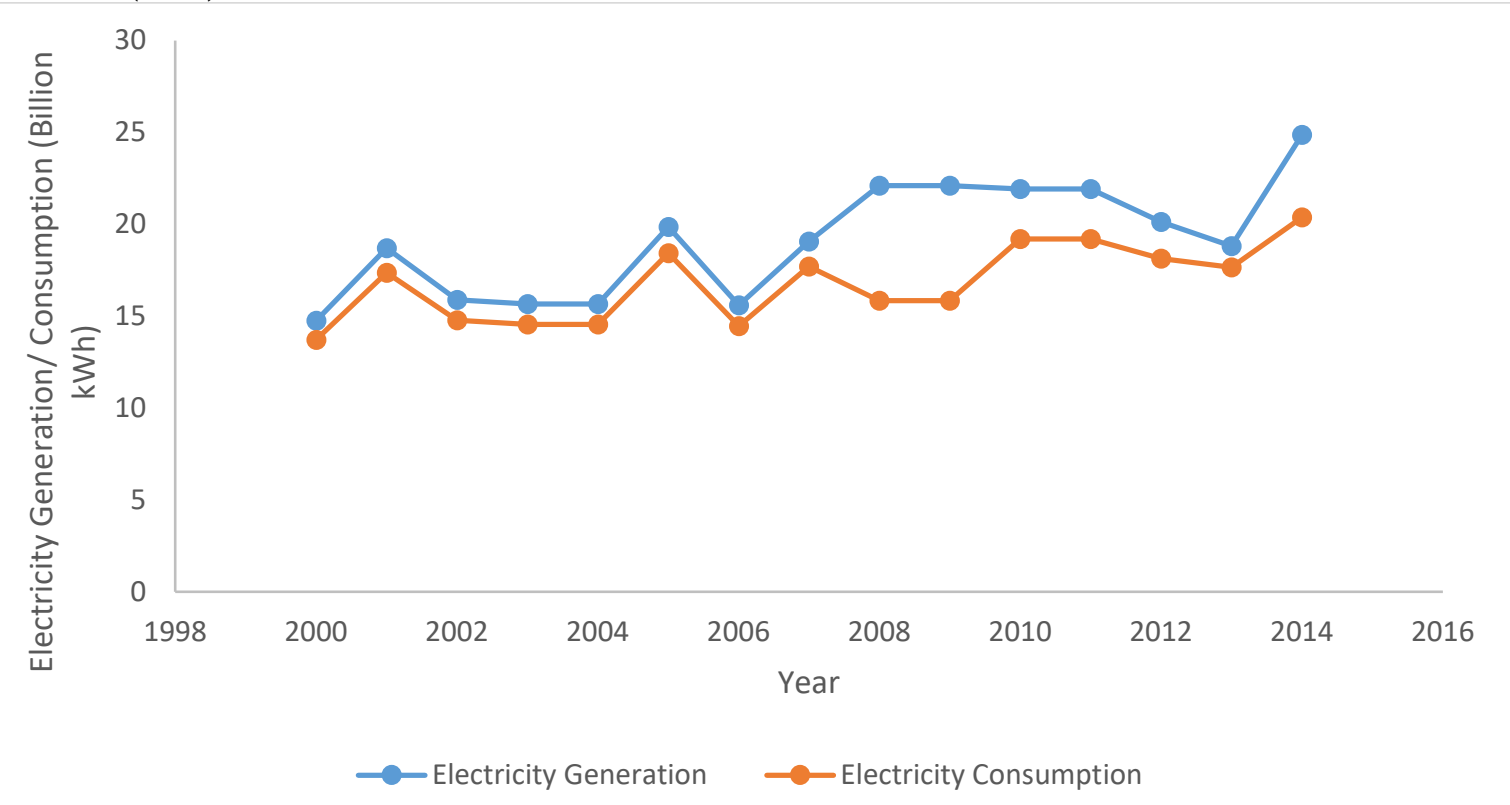

Figure 4. Electricity production and consumption in Nigeria (2000-2014). Source: Constructed from the World Development Indicators (2014); CIA World Factbook (2014)

are low access to clean energy (electricity), increase in poverty level, poor economic development and industrialization.

Nigeria suffers from an inadequate supply of usable energy due to the rapidly increasing demand, which is typical of a developing economy. Paradoxically, the country is potentially endowed with sustainable energy resources to meet with the challenges of electricity demand. However, the major reason for the shortage of domestic electricity supply may not be unconnected to the overdependence on oil and natural gas for electricity generation and non-diversification of energy resources in the country (Oyedepo, 2012a). Hence, for sustainable development, the energy demand and supply chain must be repositioned to attain a reasonable equilibrium (Abam et al., 2014).

\section{Current and Projected Future Sectorial Energy Consumptions in Nigeria}

While, energy development means enhanced provision of energy not only in quantity, but equally in quality. Energy can be in the form of fuel, power and light etc. and is consumed by human in their daily activities. Energy is also used in the industrial process, agriculture, mining, industry and services, including transport and information 


\section{$\equiv$ Total $=$ Agricultural sector $=$ Industrial sector $=$ Transportation sector}

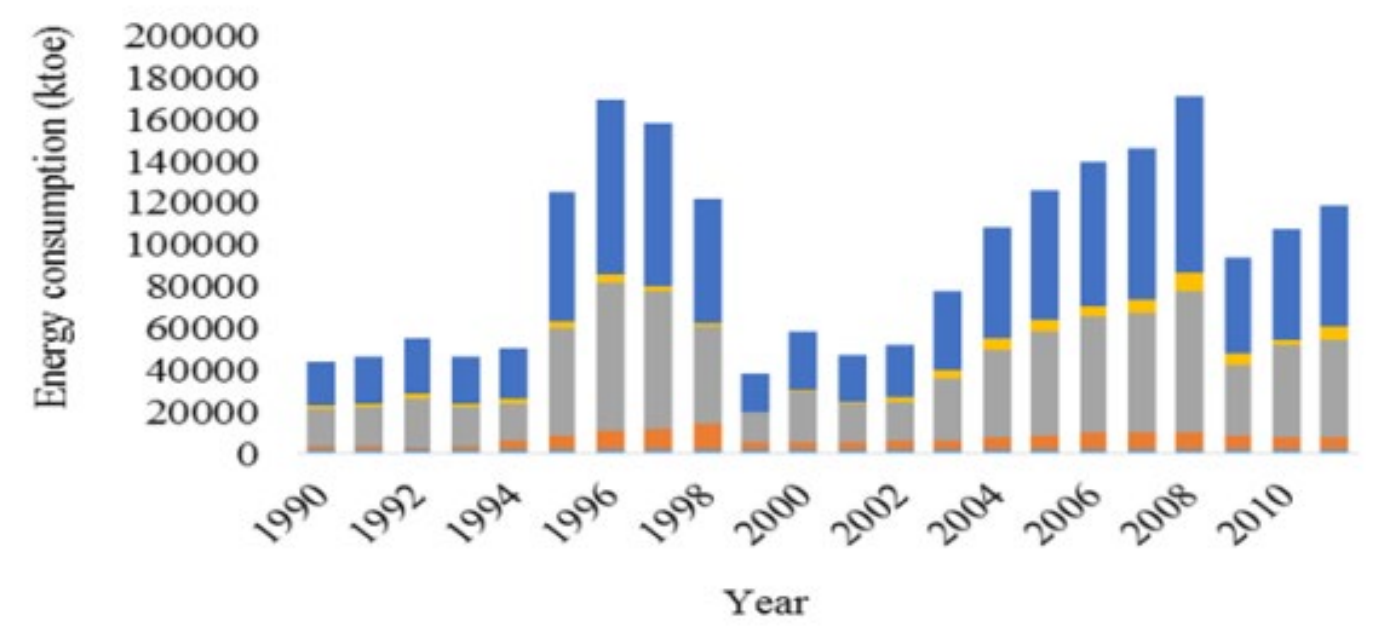

Figure 5. Energy consumption by sector from 1990-2011. Source: NBE (2011); CBN (2012)

technology sectors (Azam et al., 2015). The forms of energy consumed in Nigeria have increased in diversity and intensity with innovations in science and technology and socio-economic changes. The primary energy forms consumed in Nigeria include the major fossil fuels, such as coal and lignite, petroleum products, natural gas and wood fuel, while the major secondary form is electricity (Enibe and Odukwe, 1990).

According to (Abam and Effiom, 2015), analysis of the probable energy reserve in 2011 was given as: coal 2.7 billion tons, crude oil 37.2 billion barrels and natural gas 5.1 trillion cubic meters. The total energy consumption (EC) in 2011 was estimated at $3.6 \%$ over that in 2010 bringing the value of the aggregate consumption to approximately 4.4 quadrillions (NBS, 2011; CBN, 2012). The energy consumption profile for the three economic sectors of Nigeria, industrial, agricultural and transportation is presented in Figure 5. The industrial sector witnessed an increase in energy usage from 2002 to 2008 and declined in 2009 and then increased slightly by 2011. The transportation sector fared to drop its share to the nation's EC from $10.12 \%$ in 2008 to $9.76 \%$ in 2011. Lastly, energy usage in the agricultural sector did not exceed $2.5 \%$ in $2000,7.5 \%$ in 2006 but increase to $10.0 \%$ in 2011.

The inability to satisfy the domestic and, to a large extent, industrial needs for electricity is reported to have had debilitating impact on the growth potentials of the Nigerian economy (World Bank, 1991). Even so, the demand for electricity, according to the defunct PHCN, is projected to increase from $5746 \mathrm{MW}$ in 2005 to nearly 297,900 MW by the end of 2030. This implies that the Nigerian power sector needs to add approximately 11,686 MW of electricity to its stock each year in order to match this projection (Iyke, 2015).

In order to produce reasonable electricity supply targets and milestones, it is imperative to have energy demand and supply projections for the country using internationally accepted energy modelling techniques (Osueke and Ezeh, 2011). Among the internationally accepted energy modelling techniques used by Energy Commission of Nigeria (ECN) to analysed the energy demand and supply projections in Nigeria as reported by Sambo (2008) are Model for Analysis of Energy Demand (MAED) and Model for the Energy Supply Strategy, Alternatives and their General Environmental Impact (MESSAGE) (IAEA/ECN,2007).

In modelling the Nigeria's energy case based on MAED, four economic scenarios were developed and used as follows in accordance to International Atomic Energy Agency (IAEA, 2009):

\section{Reference Scenario - 7\% GDP Growth;}

- The main driver of growth is the manufacturing sector.

- GDP grows by an average of 7\% p.a

- Manufacturing accounts for 15\% of GDP by 2030 from 6\% in 2005 .

- Per capita electricity consumption increase to $4,000 \mathrm{kWh}$.

- Consistent with the MDG objective of reducing poverty by half by 2015 .

High Growth Scenario - 10\% GDP Growth;

- GDP grows by an average of $10 \%$ p.a

- Manufacturing contributes $24 \%$ of GDP by 2030

- Per capita electricity increase to $5026 \mathrm{kWh}$ by 2030 


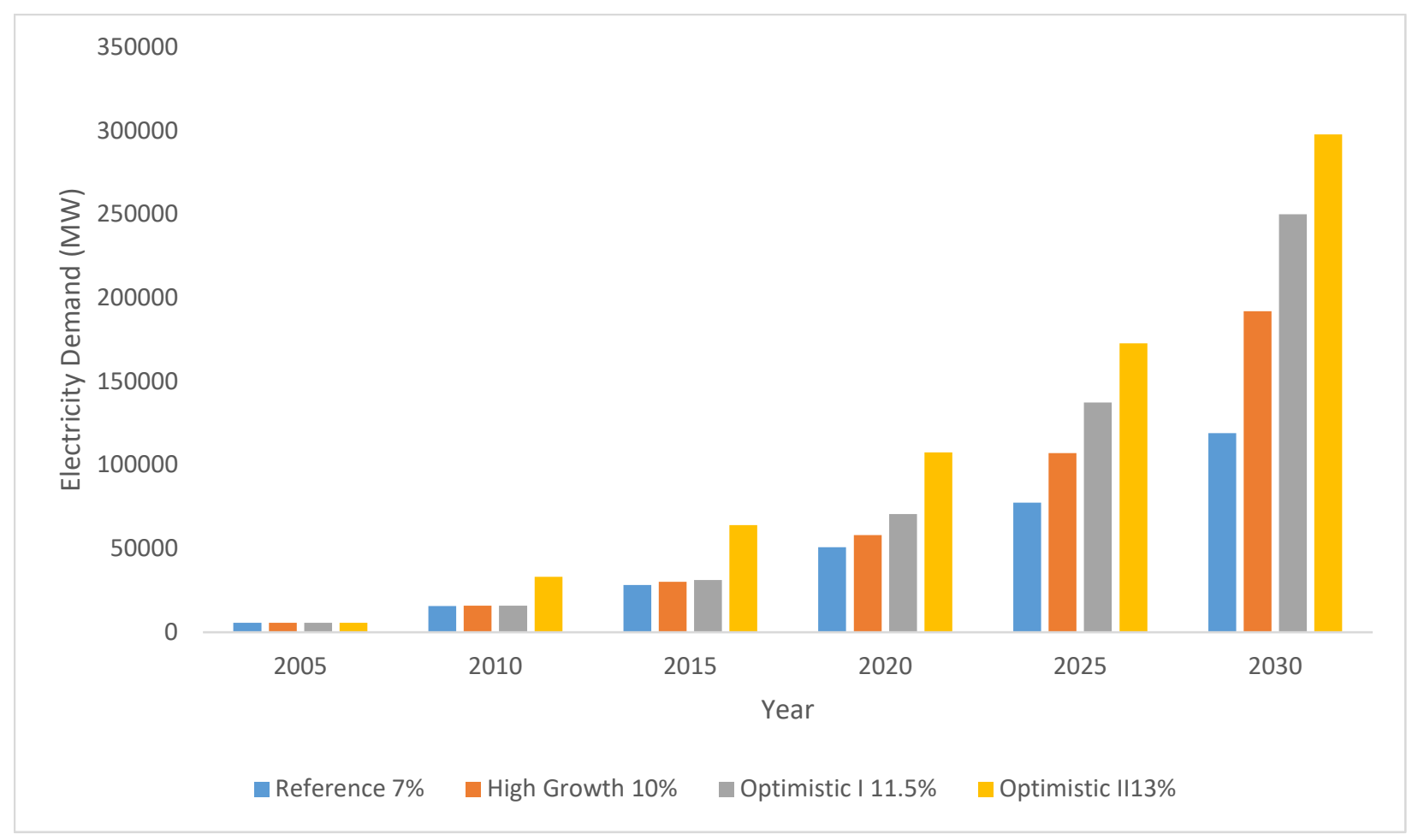

Figure 6. Electricity Demand Projections Per Scenario, MW

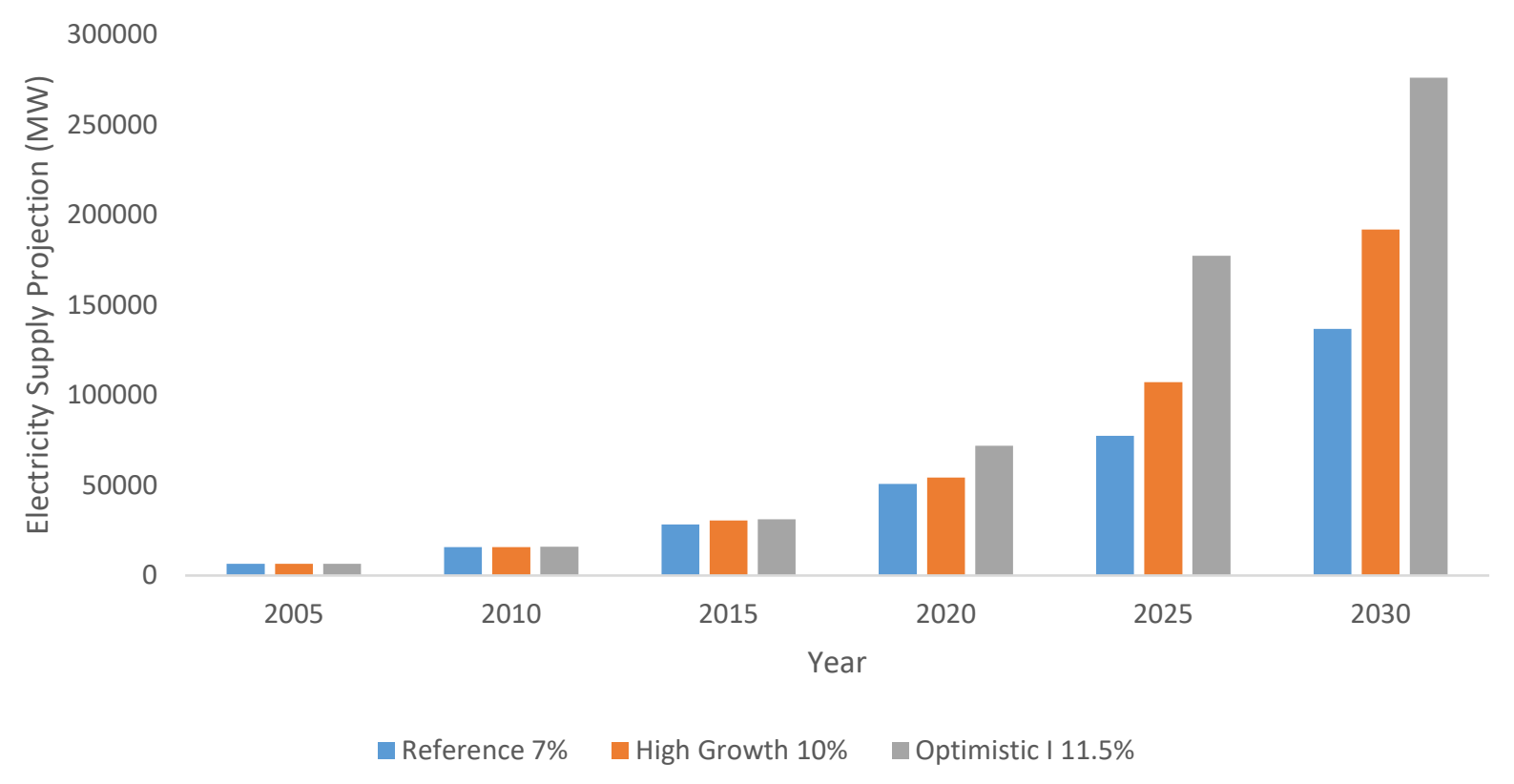

Figure 7. Electricity Supply Projection Per Scenario, MW

- Nigeria is transiting from an agrarian economy to an industrializing nation.

Optimistic Scenario I - 11.5\% GDP Growth;

- GDP grows by an average of $11.5 \%$ p.a in line current administration's vision for the economy.

- Manufacturing contributes $25 \%$ to GDP.

- Per capita electricity increase to $5,450 \mathrm{kWh}$ by 2030 .

Optimistic Scenario II - 13\% GDP Growth (based on Presidential Pronouncement for the desire to be among the first 20 economies by 2020).

- GDP grows by an average of 13\% p.a in line current administration's vision for the economy.

- Manufacturing contributes $25 \%$ to GDP.

- Per capita electricity increase to $6620 \mathrm{kWh}$ by 2030.

Figure 6 shows the electricity demand projections for the above scenarios. According to Sambo (2008), the demand indicated for 2005 represents suppressed demand, due to inadequate generation, transmission, distribution 


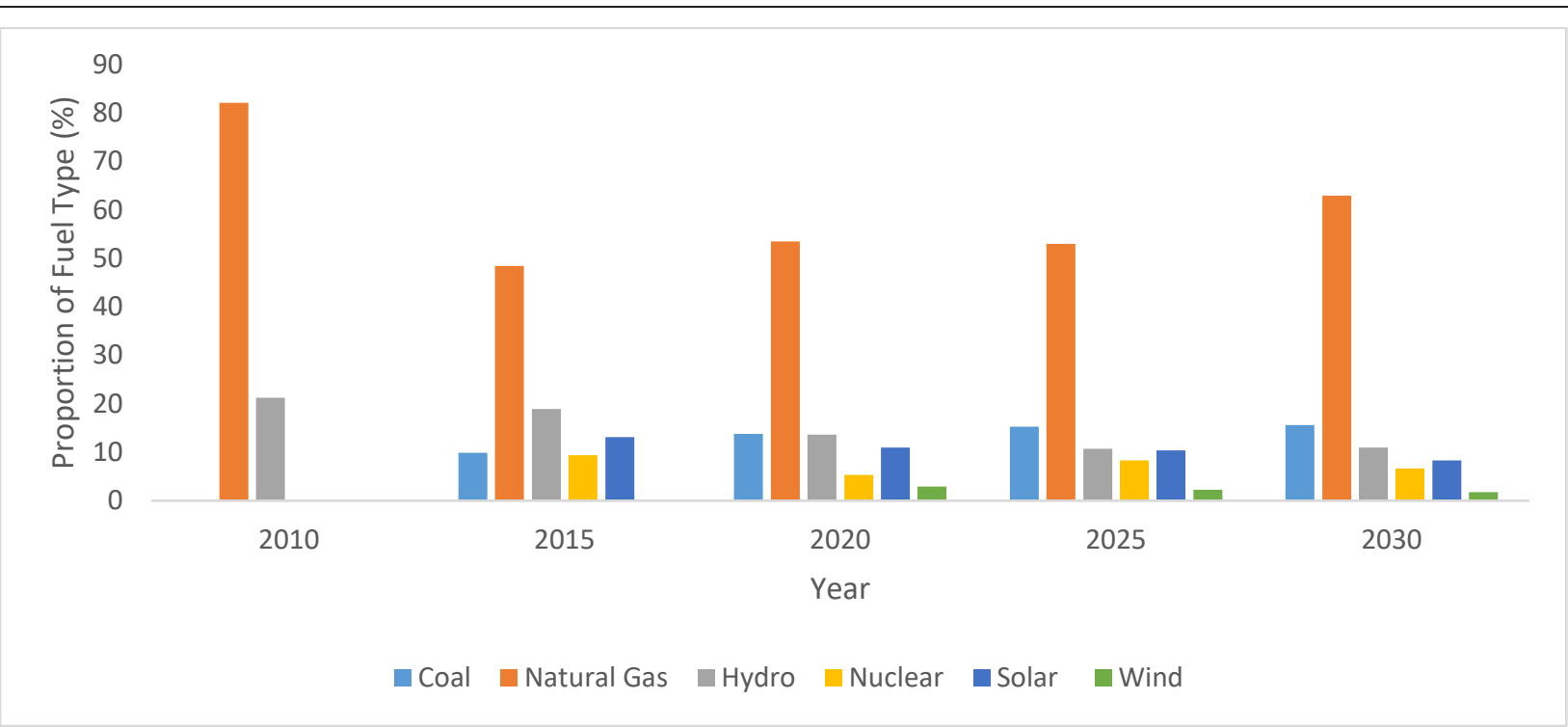

Figure 8. Future Installed Electricity Generation Capacity by Fuel (Reference Case), \%

and retail facilities. Suppressed demand is expected to be non-existent by 2010. For the 13\% GDP growth rate, the demand projections rose from 5,746MW in the base year of 2005 to $297,900 \mathrm{MW}$ in the year 2030 which translates to construction of $11,686 \mathrm{MW}$ every year to meet the demand. The corresponding cumulative investment (investment \& operations) cost for the 25 -year period is US $\$ 484.62$ billion, which means investing US\$ 80.77 billion every five years within the period. In conducting the studies, all the available energy resources in the country were considered in order to broaden the nation's energy supply mix and enhance its energy security.

The computation of Nigeria's Energy Supply projection was carried out based on MESSAGE (Osueke and Ezeh, 2011). The same scenarios used in MAED were also used. The result for the electricity supply projection is shown in Figure 7.

The following points are worthy to be noted in computing energy supply projection:

- Objective of the energy supply projections was to optimal fuel or source-mix for the diversification of the electricity supply.

- Energy supply projections used the model for energy supply strategy alternatives and their general environment model (MESSAGE).

- Scenarios are similar to that used for demand-side analysis, except for non-inclusion of the optimistic scenario II to obtain gross electricity supply projections.

- Seven fuel or source-options, including coal, gas, hydro, nuclear, wind, solar, were used for optimization. The optimization provided relative or likely contributions of each source-mix in the projected electric supply (Osueke and Ezeh, 2011).

One of the objectives of the study done with MESSAGE under the auspices of the IAEA was to find the optimal mix of fuels for the diversification of electricity supply in Nigeria. In the study, seven different fuel types (natural gas, large hydro, coal, nuclear, small hydro, solar, and wind) were used for the optimization. The shares of the different power generation technologies in the total installed capacity for the Reference Case are shown in Figure 8. From Figure 8, the share of hydropower (large and small) in the total installed capacity will decrease from $31.30 \%$ in 2005 to about $11 \%$ in 2030, while the share of natural gas based power capacity will increase from $68.30 \%$ in 2005 to $82.15 \%$ in 2010 and thereafter decrease to $62.95 \%$ in 2030 . Coal and nuclear, which are not used for power generation at all at present, will account for 15.6 and $6.7 \%$ by 2030, respectively. Solar and wind are also projected to account for $8.3 \%$ and $1.8 \%$ respectively by 2030 (Sambo, 2009).

\section{Electricity Consumption and Economic Growth Trends in Nigeria}

Using historical aggregate data on Nigeria real gross domestic (GDP) and electricity consumption (kilowatthours) the dynamic pattern of electricity consumption and economic growth in Nigeria over the period 1971-2012 is presented in Figure 9 (Okoligwe and Okezie, 2014; Iyke, 2015). The continuous increase in energy consumption is quite inconsistent with GDP but the electricity consumption has been increasing at a faster rate than GDP. From Figure 9 the dynamic pattern of electricity consumption and economic growth over the 1971-2012 is not immediately clear. At some point, it appears as if real GDP per capita growth influences the movement of the percentage change in electricity consumption per capita. For instance, when real GDP per capita growth declined from $11.8 \%$ in 1971 to $3.8 \%$ in 1972, the impact on the percentage change in electricity consumption per capita was only shown in 1972. The percentage change in electricity consumption per capita declined from $17.3 \%$ in 


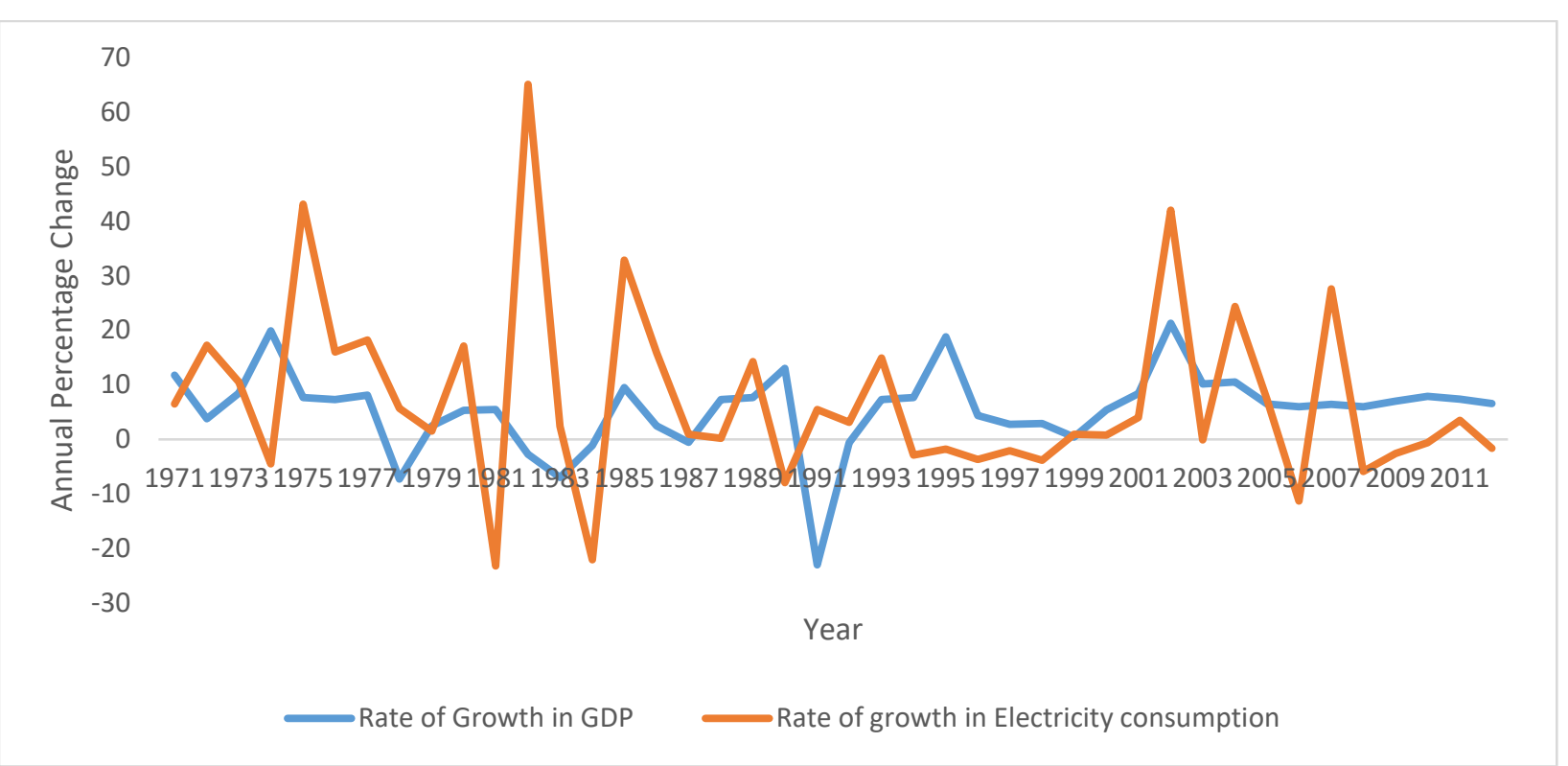

Figure 9. Rate of Growth in GDP and Electricity Consumption in Nigeria (1971-2012). Source: Constructed from the CIA World Factbook, Nigeria (2014)

Table 3. Distribution of households without electricity access in the different geo-political zones of Nigeria (in Percentage)

\begin{tabular}{|c|c|c|c|c|c|c|c|c|c|c|c|}
\hline North West & $\%$ & North central & $\%$ & North East & $\%$ & South West & $\%$ & South East & $\%$ & South - South & $\%$ \\
\hline Jigawa & 56.5 & Benue & 72.0 & Adamawa & 71.4 & Ekiti & 15.2 & Abia & 33.3 & Akwa Ibom & 38.3 \\
\hline Kaduna & 42.4 & Kogi & 48.1 & Bauchi & 58.5 & Lagos & 0.3 & Anambra & 38.3 & Bayelsa & 36.9 \\
\hline Kano & 56.2 & Kwara & 38.5 & Borno & 77.3 & Ogun & 20.4 & Ebonyi & 68.1 & Cross River & 46.3 \\
\hline Katsina & 59.7 & Nassarawa & 70.6 & Gombe & 55.4 & Ondo & 41.9 & Enugu & 48.5 & Delta & 46.3 \\
\hline Kebbi & 54.4 & Niger & 56.6 & Taraba & 88.8 & Osun & 33.9 & Imo & 12.6 & Edo & 15.2 \\
\hline Sokoto & 69.5 & Plateau & 71.3 & Yobe & 78.0 & Oyo & 38.8 & & & Rvers & 21.7 \\
\hline Zanfara & 77.1 & & & & & & & & & & \\
\hline Average & 59.4 & Average & 59.5 & Average & 71.6 & Average & 25.1 & Average & 40.2 & Average & 34.1 \\
\hline
\end{tabular}

Source: NBS (2009)

1972 to $-4.5 \%$ in 1974. In addition, when real GDP per capita growth increased from $-7 \%$ in 1983 to $9.5 \%$ in 1985, the percentage change in electricity consumption per capita was only affected after 1984 increasing from $-22.1 \%$ to $32.9 \%$ in 1985 . In contrast, when the real GDP per capita growth was on the decline between 1974 and 1975, the percentage change in electricity consumption per capita was increasing during this period. On this evidence, it is quite unclear whether electricity consumption causes economic growth or economic growth causes electricity consumption.

Despite the importance of infrastructural services to economic development, the consumption of electricity in Nigeria has been very low due to inadequate supply (Oseni, 2011). This possibly might have been responsible for the slow rate of development in the country. The most regrettable situation is that electricity sector has never contributed up to $2 \%$ and $1 \%$ to the economic value added and economic development respectively in the country. In 2010 , Nigeria electricity contributes only $0.32 \%$ and $0.22 \%$ to economic value added and economic growth respectively (Oyedepo et al., 2014). This possibly reflects the poor state of infrastructural developments in the country and the reason why Nigeria is ranked among the top poor economies in the world despite its abundant natural endowment.

\section{Electricity Access in Nigeria}

Electricity access is low in Nigeria which is the largest economy in Africa in terms of GDP and population (Emodi and Yusuf, 2015). At present, only 10\% of rural households and 40\% of the country's total population have access to electricity (Oseni, 2012). Among those who have access, a comparable number receive electricity services that are below the standards of quantity and reliability expected of an efficiently performing sector. The situation is significantly different at different geopolitical zones. Table 3 shows distribution of households without electricity access in the different geo-political zones of Nigeria (in Percentage). From Table 3, it is observe that the lack of electricity access is more severe in the northern parts of Nigeria with the North-East geopolitical zone having $71.6 \%$. 


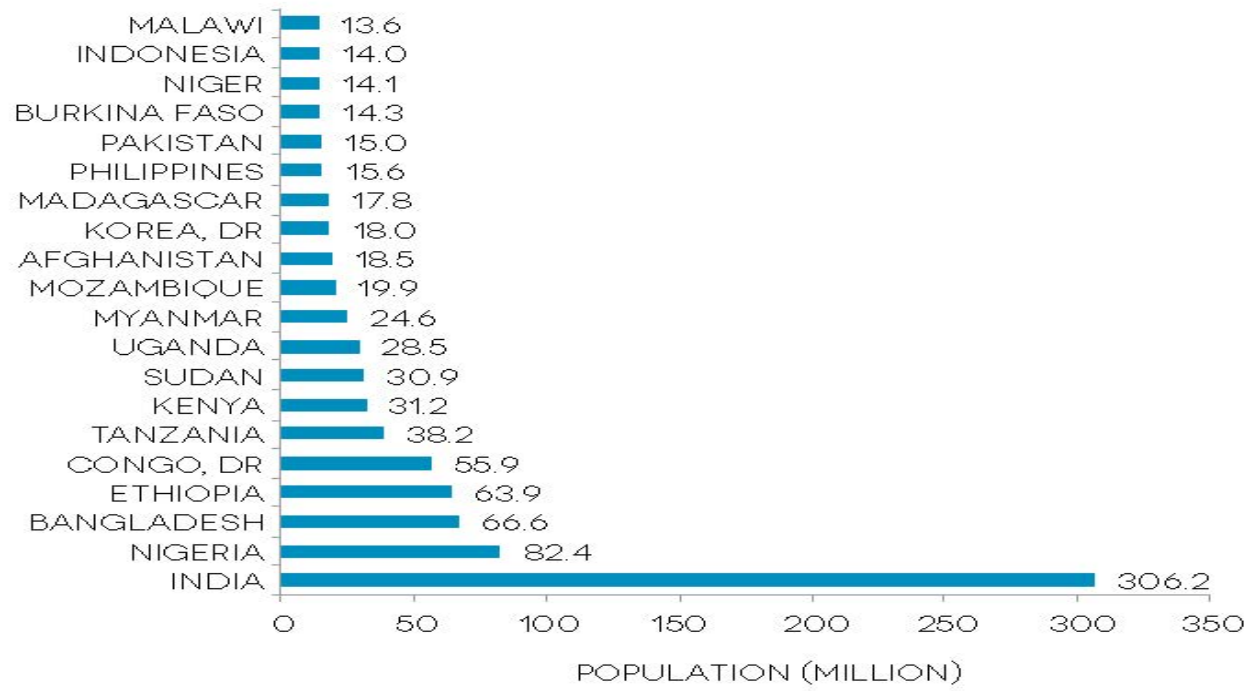

Figure 10. The 20 countries with the highest deficit in access to electricity in 2010. Source: World Bank Global Electrification Database, 2012; WHO - Global Household Energy Database, 2012

A report released by the World Bank and some foreign organizations has shown Nigeria taking the ignominious position of the second worst country with high electricity access deficit. The report states that 82.4 million Nigerians lack access to electricity. In an assessment of the worst 20 countries in the world, Nigeria came second to India with a population of 306.2 million people with lack of access to electricity (Figure 10). Unfortunately, while India, China, Indonesia, Pakistan, Bangladesh, Brazil, Philippines are moving very fast to resolve the challenge ahead of the Sustainable Energy for All by 2030, Nigeria is lagging with an annual increase in the access to electricity at the rate of 1.8 percent (Sustainable Energy for All Initiative, 2012).

Electricity access is more than just a connection to a distribution network; it requires that electricity is provided adequately as demanded and in a reliable, affordable manner. The provision of adequate and reliable electricity service on demand requires a balanced, planned expansion of generation capacity and transmission and distribution (T\&D) for delivering electricity securely and efficiently, based on the location of generation plants and load centers, and coordinating with off-grid options where feasible. Policies and regulation are needed to achieve this, both to facilitate the large capital investments needed to bridge the access gap and to ensure that electricity services are financially viable and affordable for all, especially the poor (Heider et al., 2015).

Energy security and improving access to energy are very important for local and national economic development. This can be realized in ways that also reduce health risks (through reduction of indoor and outdoor air pollution), and mitigating climate change through lower emissions of $\mathrm{CO}_{2}$.

Shifts from conventional energy system (coal, petroleum products) to non-conventional domestic renewable energy supply (bioenergy, wind power, hydropower) lead to a more diverse and cleaner energy supply (Kok et al., 2008).

There is no doubt that the present power crisis afflicting Nigeria will persist unless the government diversifies the energy sources in domestic, commercial, and industrial sectors and adopts new available technologies to achieve sustainable development through energy security while at the same time combat the challenges of global warming (Emodi and Ebele, 2016). In diversifying energy sources that is sustainable, effective utilization of renewable energy (RE) in decentralized form becomes the best option. Globally, there has been upward trend in the utilization of renewable energy in the generation of modern energy (electricity) (Oseni, 2012). The level of utilization of Nigeria's $\mathrm{RE}$ resources requires serious attention to salvage the country from a looming energy crisis.

\section{Energy Resources Potential in Nigeria}

Energy resources of a country refer to the stock of materials and resources from which energy can be drawn with given present know- how. Energy resources are among the most important assets of any nation. It is a wellknown fact that high rate of industrial growth is a function of the amount of energy available and the extent to which that energy is utilized (Shaaban and Petinrin, 2014).

Nigerian energy resources are categorized into conventional and non-conventional forms. The conventional energy resources consist of coal, crude oil, natural gas and hydroelectric power and lignite. The non-conventional energy resources in Nigeria include solar, nuclear fuels, geothermal, biomass, oil shales, tar sand, wind and tidal from sea (Nwanya, 1998). Table 4 and Figure 11 show the energy resources potential in Nigeria and the geographical distribution of these energy resources. From Table 4, it is seen that Nigeria is endowed with an abundant supply of natural energy sources, both fossil and renewable. These diverse resources are available all over 
European Journal of Sustainable Development Research, 2(4), 40

Table 4. Energy Resources of Nigeria

\begin{tabular}{|c|c|c|c|c|c|}
\hline \multicolumn{3}{|c|}{ S/NoResource Type } & Reserves (Natural Units) & Product Level(Natural Units) & Utilization (Natural Units) \\
\hline 1 & \multicolumn{2}{|c|}{ Light Crude oil } & 37.06 billion bbl (as at 2017) & 2.5 million barrels/day (as at 2014) & $316,000 \mathrm{bbl} /$ day (as at 2015) \\
\hline 2 & \multicolumn{2}{|c|}{ Natural Gas } & 5.284 trillion CUM (as at 2017) & 45.15 billion CUM (as at 2014) & 26.86 billion CUM (as at 2015 ) \\
\hline 3 & \multicolumn{2}{|c|}{ Coal and Lignite } & 2.734 billion tonnes & Insignificant & Insignificant \\
\hline 4 & \multicolumn{2}{|c|}{ Tar Sands } & 31 billion barrels of oil equivalent & - & - \\
\hline 5 & \multicolumn{2}{|c|}{ Large Hydropower } & $11,250 \mathrm{MW}$ & 1,938MW(167.4 Million MWh/day) & 167.4 Million MWh/day \\
\hline 6 & \multicolumn{2}{|c|}{ Small Hydropower } & $3,500 \mathrm{MW}$ & $30 \mathrm{MW}(2.6$ million MWh/day) & 2.6 Million MWh/day \\
\hline$\overline{7}$ & \multicolumn{2}{|c|}{ Solar Radiation } & $\begin{array}{l}3.5-7.0 \mathrm{kWh} / \mathrm{m}^{2} / \text { day }(485.1 \\
\text { million } \mathrm{MWh} / \text { day using } 0.1 \% \\
\text { Nigeria land area) }\end{array}$ & $\begin{array}{c}\text { Excess of } 240 \mathrm{kWp} \text { of solar PV or } \\
0.01 \text { million } \mathrm{MWh} / \text { day }\end{array}$ & $\begin{array}{l}\text { Excess of } 0.01 \text { million } \\
\mathrm{MW}_{\mathrm{p}} \mathrm{h} / \text { day of solar PV }\end{array}$ \\
\hline 8 & Wind & & $2-4 \mathrm{~m} / \mathrm{s}$ at $10 \mathrm{~m}$ height & - & - \\
\hline \multirow[t]{3}{*}{9} & \multirow{3}{*}{ Biomass } & Fuel wood & $\begin{array}{l}11 \text { million hectares of forest and } \\
\text { wood land }\end{array}$ & 0.110 million tonnes/day & 0.120 million tonnes/day \\
\hline & & $\begin{array}{l}\text { Animal } \\
\text { waste }\end{array}$ & 245 million assorted in 2001 & $\begin{array}{l}0.781 \text { million tonnes of waste/day } \\
\text { in } 2001\end{array}$ & Not available \\
\hline & & $\begin{array}{l}\text { Energy } \\
\text { Drops \& } \\
\text { Agric } \\
\text { Residue }\end{array}$ & $\begin{array}{l}72 \text { million hectares of Agric land } \\
\text { and all waste lands. }\end{array}$ & $\begin{array}{c}\text { Excess of } 0.256 \text { million tonnes of } \\
\text { assorted crops residues/day in } \\
1996 .\end{array}$ & Not available \\
\hline 10 & Nuclear elen & & Not yet quantified & - & - \\
\hline
\end{tabular}

\section{Source: Sambo 2018}

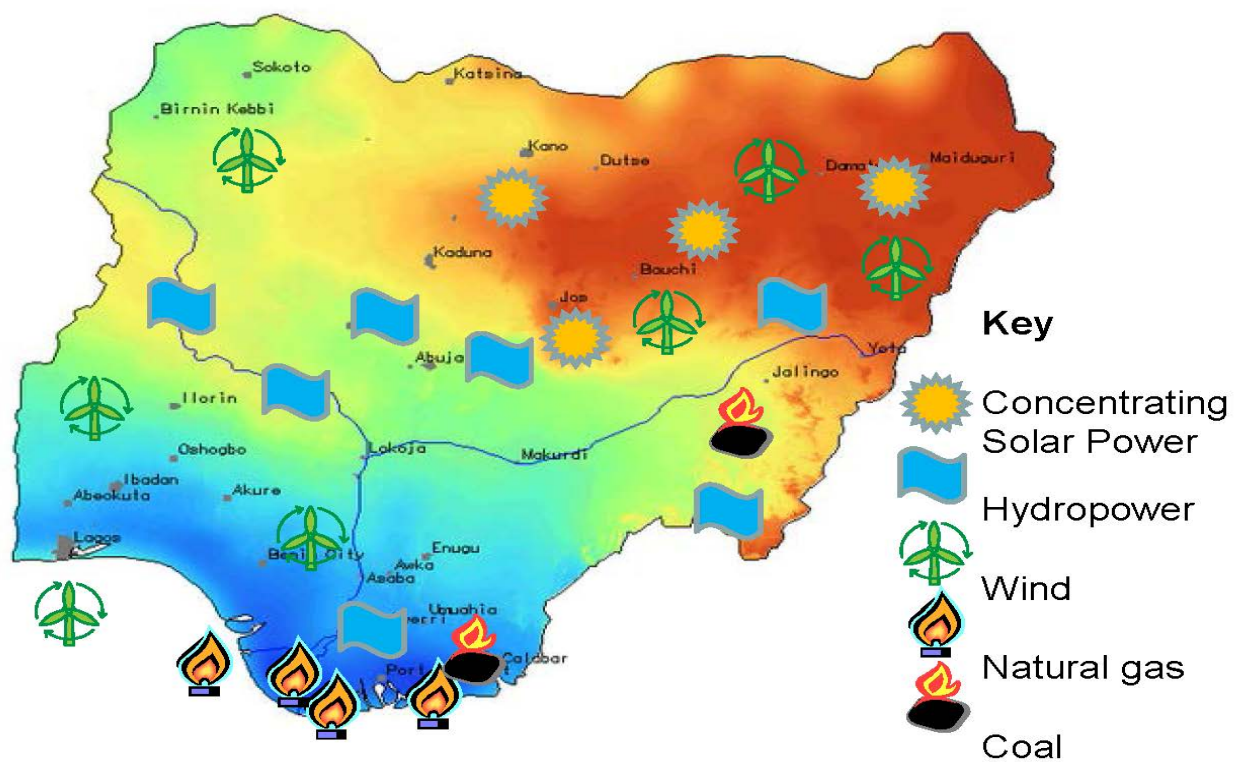

Figure 11. Diversity of geographic distribution of Nigeria's portfolio of energy sources

the country. Figure 11 provides a general indication of regions in Nigeria with high potential for selected energy resources. If these resources are properly harnessed and effectively managed, Nigeria would have been among the richest energy generation in the world. Unfortunately, some of these resources are yet to be tapped while the maximum utilization of others is not in view, thus making energy a major concern and priority in the country. Hence, rapid growth in the energy need above generation levels and poor access have therefore always been the result of resources underutilization and a major constraint to economic growth.

Energy plays a double role in Nigeria's economy: as an input into all economic activities and as the mainstay of Nigeria's foreign exchange earnings through the export of crude oil and, more recently, from increasing natural gas exports. Nigeria's economy is heavily dependent on the oil sector and now on gas too, since both together account for $90-95 \%$ of export revenues, over $90 \%$ of foreign exchange earnings and nearly $80 \%$ of government revenues. The majority of Nigeria's exports of crude are destined for markets in the United States and Western Europe with Asia becoming an increasingly important market of late (Oyedepo, 2013).

The Nigeria National Petroleum Corporation (NNPC) revealed that Nigeria's oil production in 2014 stood at 2.5 million barrels per day (bbl/day) making it the $13^{\text {th }}$ largest producer of crude oil in the world. It also holds the $9^{\text {th }}$ largest natural gas reserves in the world. However, its gas-dominated electricity grid still experiences frequent collapses due to inadequate gas supply and obsolete infrastructures.

Many indigenous researchers have looked into the availability of renewable energy resources in Nigeria with a view to establishing their viability in the country. In this regard, the potential of generating electricity through the following renewable energy resources in Nigeria such as solar energy, wind energy, hydropower and biomass has 


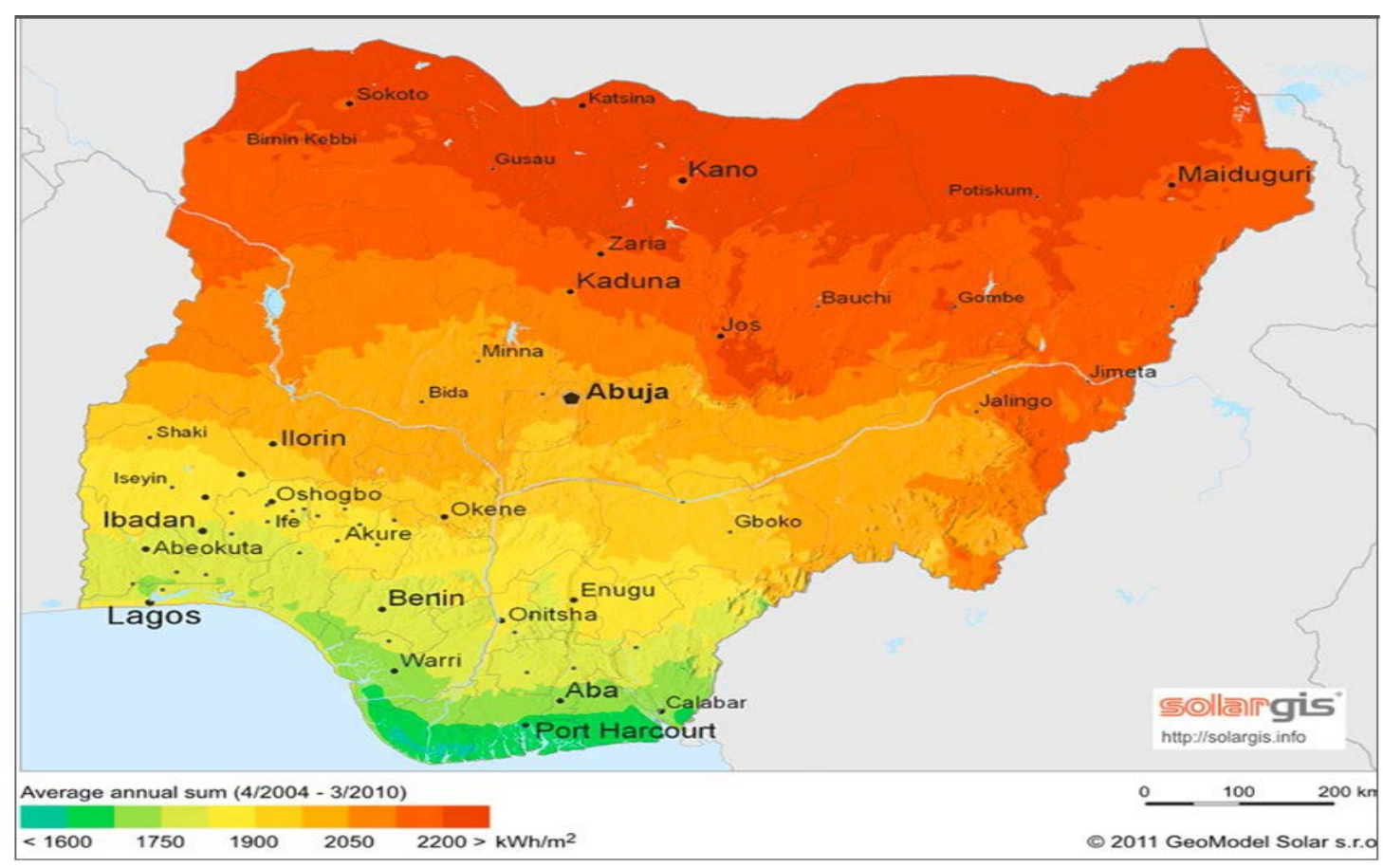

Figure 12. Solar Irradiation Levels of Global Horizontal Irradiation (GHI) in Nigeria

been established and confirmed feasible (Adaramola and Oyewola, 2011; Agbetuyi et al., 2012, Oji et al., 2012, Ladan, 2009). For example, Nigeria's annual average daily solar radiation is about $5.535 \mathrm{kWh} / \mathrm{m}^{2} /$ day, varying between $3.5 \mathrm{kWh} / \mathrm{m}^{2} /$ day and $7.0 \mathrm{kWh} / \mathrm{m}^{2} /$ day at the coastal areas in the south and at the northern boundary respectively.

Nigeria has a potential for electricity production from Solar PV technology in the range of 207,000 GWh per year if theoretically only $1 \%$ of the land area (e.g. $920 \mathrm{~km}^{2}=920 \times 10^{6} \mathrm{~m}^{2}$ ) were covered with state-of-the-art polycrystalline PV modules, with an electricity yield of 1,500 Wh/Wp per year. This figure is tenfold the total electricity production of Nigeria in 2011. As can be seen from the map in Figure 12, the best potential for large-scale solar power plants (preferably PV) lies in the northern part of the country. Long-term annual average global horizontal irradiation (GHI) values in the northern states ranges from 2,000 to $2,200 \mathrm{kWh} / \mathrm{m}^{2}$. This high solar irradiation is comparable to very high-yield sites in southern Spain, northern Africa, Australia and Latin America. The south of Nigeria has less potential for solar energy as it is often cloudy and has a longer rainy season.

The World Bank recommends in this context that off-grid solutions be developed using renewable energy sources, commenting that "PV and bybrid systems are already economically competitive for many off-grid applications. Gasoline and diesel generators produce power at levelised cost of energy (LCOE) between US\$0.23 and $\$ 0.42 / \mathrm{kWh}$. The cost of electricity from $P V$ and hybrid $P V$-wind diesel systems are in the range of $\$ 0.30 / \mathrm{kWh}$ and $\$ 0.22 / \mathrm{kWh}$, respectively. As the costs of renewables continue down the learning curve, and fossil fuel prices in Nigeria revert to global market prices ("export parity"), the economic advantages of renewables will become ever greater." It proposes that solar PV in particular be used for water pumping and irrigation (IEA, 2014).

Wind energy resource in Nigeria is available at an annual average speed of $2.0 \mathrm{~m} / \mathrm{s}$ near the coast to $5.0 \mathrm{~m} / \mathrm{s}$ at the height of $10 \mathrm{~m}$ in northern parts of the country. The Ministry of Science and Technology has carried out wind energy resource mapping (Lahmeyer, 2005). This wind mapping project indicated wind speed of up to 5 meters per second in the most suitable locations, which reveals only a moderate and local potential for wind energy.

The highest wind speeds can be expected in the Sokoto region, the Jos Plateau, Gembu and Kano / Funtua. The stations at Maiduguri, Lagos and Enugu also indicated fair wind speeds, sufficient for energy generation by wind farms. Apart from these sites, other promising regions with usable wind potential are located on the Nigeria western shoreline (Lagos Region) and partly on the Mambila Plateau. The calculations indicate the highest energy yield at the coastal area of Lagos, followed by the Sokoto area and the Jos Plateau. The computed 3D wind map is shown in Figure 13. To date, the Federal Ministry of Power reports that an off-shore wind mapping is being undertaken (Vincent - Akpu, 2012). However, no details about this have been disclosed. Such information would beneficial for further investigation of the potential of wind power in Nigeria. There are two larger wind farm projects ongoing at present, namely 10 MW in Katsina, and 100 MW in Plateau State. As regards the 100 MW wind-power farm outside Jos, due diligence has been completed on the application for a license to operate. The owner reports that a provisional Independent Power Producer (IPP) license has been obtained from the National Electricity Regulatory Commission (NERC) acknowledging that JBS Wind Power Limited has met all regulatory 


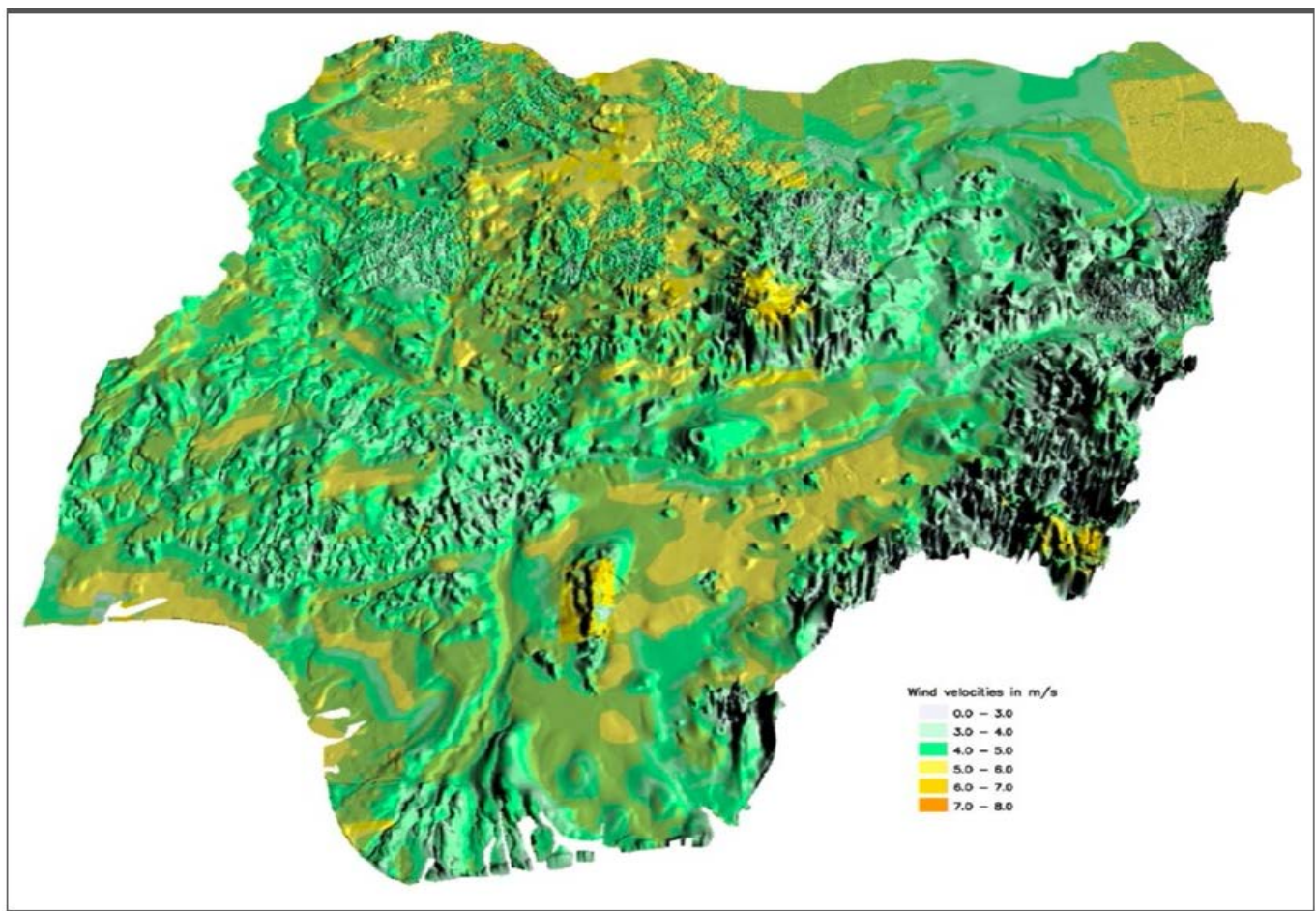

Figure 13. A 3D Wind Map of Nigeria $80 \mathrm{~m}$ above the Ground. Source: Ministry of Science and Technology, Nigeria 2005

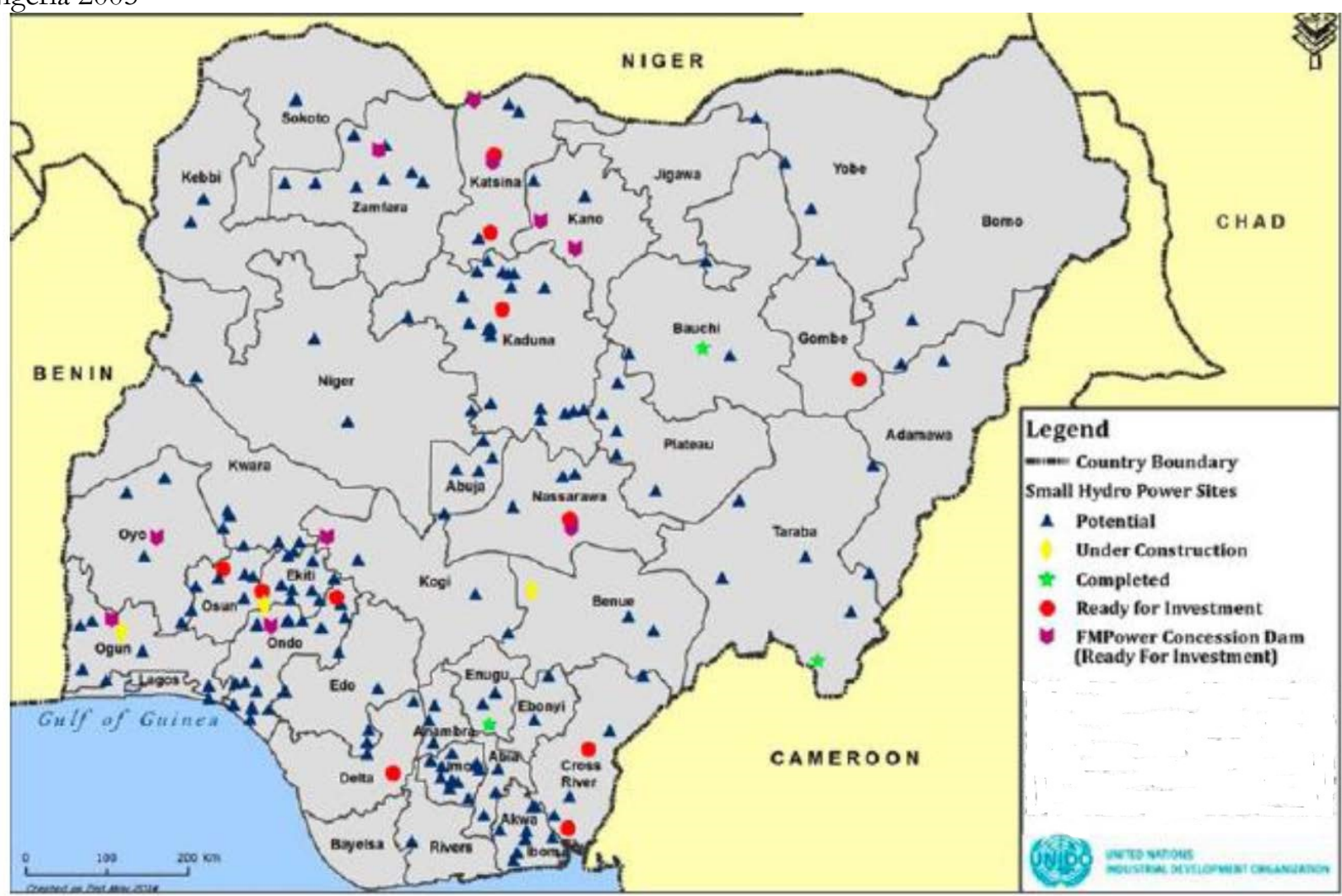

Figure 14. Small Hydro Power Sites in Nigeria. Source: CRET (2015)

requirements to commence operation. The smaller $10 \mathrm{MW}$ Katsina pilot wind farm is being built by a French company on behalf of the Federal Ministry of Power (FMP) and is about to be completed (FMP, 2015).

Nigeria ranked ninth in hydropower potential in Africa with technical hydropower energy at 32,450 GWh/yr. As at 2001, only 21.5\% (6986 GWh/yr) of the hydro potential was used. Currently there are $1.9 \mathrm{GW}$ hydropower capacity installed in 3 large power plants (Kainji: 760 MW; Jebba: 570 MW; Shiroro: 600 MW), although only roughly half of it is operational (NERC, 2012). A World Bank reference scenario following Federal Government of Nigeria (FGN) plans and feedback from stakeholders suggests hydropower utilization could be increased to 7.2 GW by 2035 (World Bank, 2013). The ECN estimates the large hydro potential even at $11250 \mathrm{MW}$ and the small 
Table 5. Small Hydro Potentials in Surveyed States in Nigeria

\begin{tabular}{|c|c|c|c|c|c|}
\hline Selected State & River Basin & Total Sites & $\begin{array}{c}\text { Potential Capacity } \\
\text { (MW) }\end{array}$ & $\begin{array}{c}\text { Developed Capacity } \\
\text { (MW) }\end{array}$ & $\begin{array}{c}\text { Under Developed Capacity } \\
(\mathrm{MW})\end{array}$ \\
\hline Sokoto & Sokoto - Rima & 22 & 30.60 & 8 & 22.6 \\
\hline Katsina & Sokoto - Rima & 11 & 234.34 & - & 234.34 \\
\hline Adamawa & Upper Benue & 3 & 28.60 & - & 28.60 \\
\hline Niger & Niger & 30 & 117.60 & - & 117.60 \\
\hline Kaduna & Niger & 19 & 59.20 & - & 59.20 \\
\hline Ogun & Niger & 13 & 15,61 & - & 15.61 \\
\hline Kwara & Niger & 12 & 38.8 & - & 38.8 \\
\hline Kano & Hadejia-Jamare & 28 & 46.2 & 6 & 40.2 \\
\hline Bauchi & Upper Benue & 20 & 42.6 & - & 42.6 \\
\hline Gombe & Upper Benue & 2 & 35.099 & - & 35.099 \\
\hline Taraba & Upper Benue & 9 & 134.72 & - & 134.72 \\
\hline Platean & Lower Benue & 32 & 110.40 & 18 & 92.40 \\
\hline Benue & Lower Benue & 19 & 69.20 & - & 69.20 \\
\hline Cross Rivers & Cross Rivers & 18 & 28.10 & - & 28.10 \\
\hline Total & & 238 & 991.069 & 32 & 959.069 \\
\hline
\end{tabular}

Sources: Ismaila (2006); Kela et al., (2012); Shaaban and Petinrin.(2014)

hydro potential at 3500 MW (ECN, 2013). In spite of this huge potential, hydropower capacity in Nigeria still remains underexploited. Current hydropower generation is about $14 \%$ of the nation's hydropower potential and represents some $30 \%$ of total installed grid connected electricity generation capacity of the country (Oyedepo, 2014c).

Recently, small hydropower (SHP) has gained rapid consideration in both the developed and developing economies of the world because of its inherent advantages like in-excessive topography problems, reduced environmental impact, minimal civil works and the possibility for power generation alongside with irrigation, flood prevention, navigation and fishery. According to the recent studies carried out by Energy Commission of Nigeria (ECN), hydropower potential sites are distributed in 12 States and in the river basin. However, SHP potential sites exist in virtually all parts of Nigeria (Figure 14). There are over 278 unexploited sites (Table 5) with total potentials of 734.3 MW (Essan, 2003; Ismaila, 2006). So far about eight (8) small hydropower station with aggregate capacity of 37.0 MW has been installed in Nigeria by private company and the government. Some around Jos Plateau, where there is 2 MW Station at Kwall fall on N'Gell river (river Kaduna) and 8MW station at Kurra fall, which was developed by a private company (NESCO) more than 75 years ago. The technically exploitable small hydro power (SHP) capability in Nigeria is high but underutilized .Hence, there is urgent need to develop Small Hydropower Plants for provision of electricity for the rural areas and remote settlements. The SHP development programme in the last year has been able to assess additional 22 potential sites for developments.

A cost comparison between small-scale hydro power plants and diesel generators for rural electrification clearly indicates the cost effectiveness of the former. It will therefore be useful for the country if more attention is paid to the exploitation of small scale hydro resources for power generation.

Studies by indigenous researchers (Ladan, 2009; Simonyan and Fasina, 2013; Ogwueleke, 2009; Agbro and Ogie, 2012; Agba et al., 2010) revealed that the country has high potential for bioenergy development because roughly 74 million ha of Nigeria's total land (98 million ha) is arable and about $60 \%$ of the arable land is lying idle.

In view of the increasing demands for electricity in the country, alternative off-grid renewable energy solutions are needed to diversify power generation from the vast supply of renewable biomass materials. Nigeria, as an agrarian economy has ample opportunity to bridge the electricity demand-supply gap by utilizing its abundant biomass resources such as agricultural residues (Garba and Zangina, 2015). The biomass resources of Nigeria can be identified as wood biomass, forage grasses and shrubs, residues and wastes (forestry, agricultural, municipal and industrial) as well as aquatic biomass (Olurinde, 2015).

From the perspective of available land and wide range of biomass resources, Nigeria has significant potential to produce biofuels and even become an international supplier. Bioenergy feedstock is not only abundant in Nigeria, it is also widely distributed. Nigeria is the largest producer of cassava in the world. Nigeria could also become a major player in the biofuel industry given the enormous magnitude of various waste / residues (agricultural, forestry, industry and municipal solid) available in the country.

The country well-endowed with abundant biomass energy resources, which are not being utilized adequately. Putting the huge quantities of biomass resources, mostly in the form of agricultural residues and wastes, which are currently disposed by burning or dumping, to energy production could potentially increase the energy supply thereby increasing energy mix and balance in Nigeria. There are also environmental benefits of reducing greenhouse gas emissions by generating electricity from biomass as well as supply of electricity in the rural areas (Pereira et al., 2012; Simonyan and Fasina, 2013). There exist a great opportunities for exploitation of different 


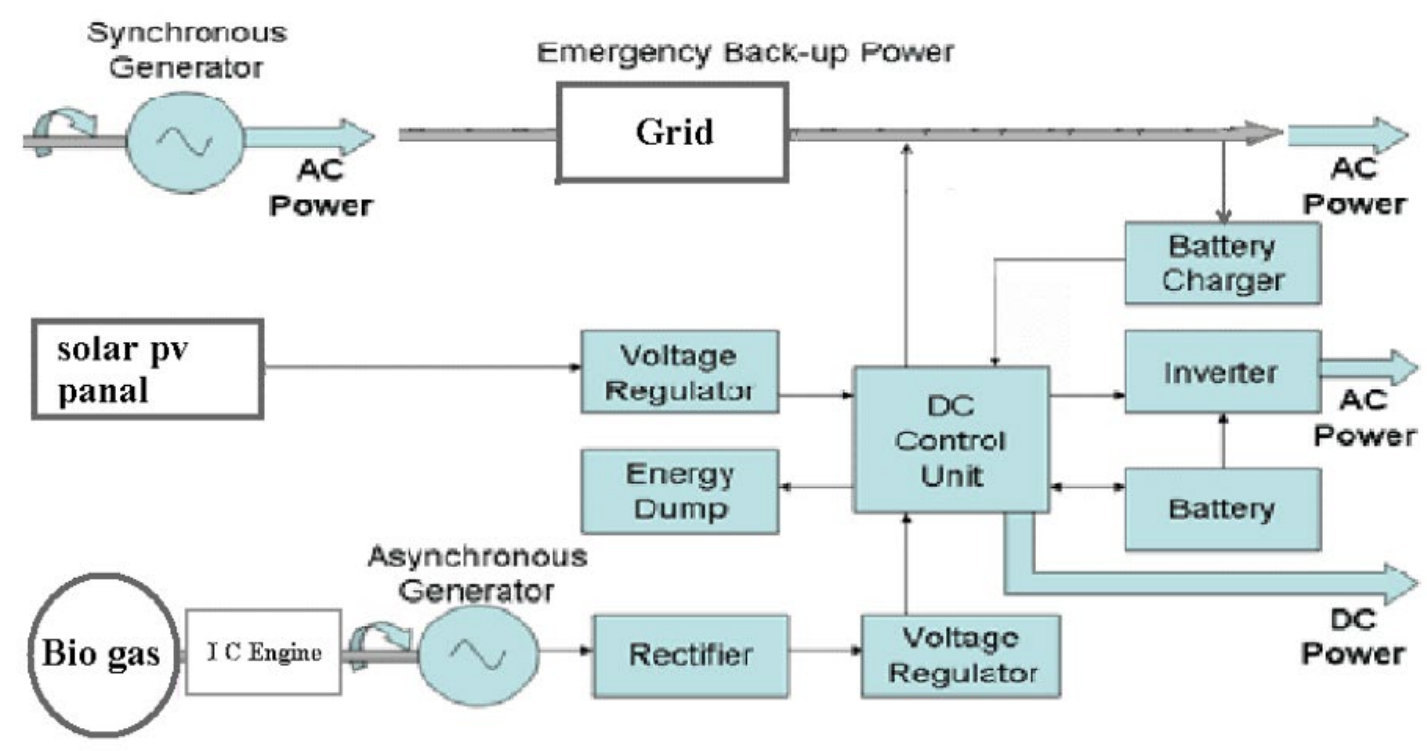

Figure 15. Hybrid Power System (Source: Bajpai and Dash, 2012)

types of biomass in Nigeria with an estimated 2.01 EJ (47.97 MTOE) biomass residues and wastes available to be exploited annually.

For energy purposes, Nigeria is using 80 million cubic metres $\left(43.4 \times 10^{9} \mathrm{~kg}\right)$ of fuel wood annually for cooking and other domestic purposes. The energy content of fuel wood that is being used is $6.0 \times 10^{9} \mathrm{MJ}$ out of which only between 5 and $12 \%$ is the fraction that is gainfully utilized for cooking and other domestic uses (Ajao et al., 2009).

According to assessment carried out by World Bank (2013), it was expected that by 2015 conversion of biomass-to-power could deliver as much as 1,643 GWh/year, with the figure rising to 13,140 GWh/year by 2035. Unfortunately, to date, there has been little mention of any plans to establish large biomass power plants, for example along the model developed in Brazil for sugarcane plantations, where the crushed fibres (bagasse) are used as the feedstock to great effect. This is even more surprising given the prevalence of academic literature demonstrating the biomass potentials on the ground in Nigeria.

\section{Hybrid Power Systems}

In the context of electric power generation, 'Hybrid System' refers to a system that uses more than one power source to produce electricity (Germany Energy Agency, 2010). A hybrid system usually consists of one or more renewable energy sources and is common with isolated power systems and weak grids. Hybrid Renewable Energy Systems (HRES) is composed of one renewable and one conventional energy source or more than one renewable with or without conventional energy sources, that works in stand- alone or grid connected mode (Lazarov et al., 2005). HRES is becoming popular for stand-alone power generation in isolated sites due to the advances in renewable energy technologies and power electronic converters which are used to convert the unregulated power generated from renewable sources into useful power at the load end. The most common hybrid combinations are PV-Diesel and Wind-Diesel (National Renewable Energy Directory, 2005).

The important feature of Hybrid Systems (Figure 15) is to combine two or more renewable power generation technologies to make best use of their operating characteristics and to obtain efficiencies higher than that could be obtained from a single power source. Hybrid systems can address limitations in terms of fuel flexibility, efficiency, reliability, emissions and economics (Bajpai and Dash, 2012).

Simple hybrid systems use batteries for immediate response to reduction in power output and diesel generators for longer lasting situations. An immediate response or primary control refers to a loss in power that needs to be countered in a matter of seconds before its effect is felt by the consumers while a longer lasting situation requires secondary control which employs mechanisms like the Automatic Generation Control (AGC) that is designed to kick in if the interruption in power delivery is not abated in about $10-15$ minutes. Prediction of a drop in power production by one energy source helps system operators to structure the hybrid model to begin firing up back up power well in advance (Adem et al., 2008).

In Nigeria, several researchers (Adaramola et al., 2012; Okundamiya and Omorogiuwa, 2015; Adaramola, 2012; Oladeji and Sule, 2015; Olatomiwa et al., 2016) have carried out studies on technical and economic feasibility of utilizing hybrid energy systems as a means of increase access to electricity in rural areas of Nigeria. As HRES combine two or more renewable sources with or without conventional energy sources helps to overcome disadvantage of power fluctuation in using single renewable energy source (Siddaiah and Saini, 2016). 


\section{SUSTAINABLE ENERGY TECHNOLOGY DEVELOPMENT}

Sustainable development may be broadly defined as living, producing, and consuming in a manner that meets the needs of the present without compromising the ability of future generations to meet their own needs. The aim of sustainable development is to achieve improvement in quality of life, including improving standards of living in less developed countries while safeguarding the ecological processes upon which life depends (Oyedepo, 2012b). In this context, the concept of sustainable energy technology (SET) refers to the energy technology that is capable of providing energy to meet consumers' needs (demands) at an affordable cost on a long-term basis without disturbing (compromising) ecological balance (Ali, 2011). That means SET is environment-friendly and cost-effective. However, the viability of SET adoption depends on the socio-economic and technical background of rural dwellers in Nigeria.

Reliable energy supply is essential in all economies for lighting, heating, communications, industrial equipment, transport, etc. Purchases of energy account for 5 to $10 \%$ of gross national product in developed economies. However, in some developing countries, fossil fuel imports (i.e. coal, oil, and gas) may cost over half the value of total exports; such economies are unsustainable, and an economic challenge for sustainable development. World energy use increased more than ten-fold during the $20^{\text {th }}$ century, predominantly from fossil fuels and with the addition of electricity from nuclear power. In the $21^{\text {st }}$ century, further increases in world energy consumption may be expected, largely due to rising industrialization and demand in previously less developed countries, aggravated by gross inefficiencies in all countries. Whatever the energy source, there is an overriding need for efficient transformation, distribution, and use of energy (Twidell and Weir, 2015).

Thus energy sustainability is considered to involve the sustainable use of energy in the overall energy system. This system includes processes and technologies for the harvesting of energy sources, their conversion to useful energy forms, energy transport and storage, and the utilization of energy to provide energy services such as operating communications systems, lighting buildings and cooking. Thus, energy sustainability goes beyond the search for sustainable energy sources, and implies sustainable energy systems, i.e., systems that use sustainable energy resources, and that process, store, transport and utilize those resources sustainably (Oyedepo, 2014a).

Sustainable energy technologies are necessary to save the natural resources avoiding environmental impacts which would compromise the development of future generations (Oyedepo, 2013). Delivering sustainable energy will require an increased efficiency of the generation process including the demand side. In attaining sustainable development, increasing the energy efficiencies of processes utilizing sustainable energy resources plays an important role. The utilization of renewable energy offers a wide range of exceptional benefits (Hepbasli, 2008).

As a complementary measure, development of renewable energy resources in Nigeria is important to promote economic growth, protect ecosystems and provide sustainable natural resources. Furthermore, renewable energy resources development in developing countries like Nigeria will promote poverty reduction, improve education quality, maternal health, gender equality, and aim at combating child mortality, AIDS and other diseases which would be in line with the Millennium Development Goals (United Nations, 2006). Moreover, the sustainable energy technologies often reduce or avoid greenhouse gases (GHGs) emissions, such projects would also address the climate change issue (Doukas et al., 2009; Karakosta et al., 2012). However, these kinds of practices are, unfortunately, rare in the country. Notwithstanding, with effective policy formulation by government and private partnership involvement in renewable energy technologies, there is guarantee of sustainable national development in Nigeria.

\section{Challenges for Sustainable Energy Technology Development in Nigeria}

Needs and availability of raw material are sadly not always guarantors of technology development. This is true in this case for sustainable energy development in Nigeria. The following are recognized potential challenges to the development of sustainable energy technology in the country:

- Lack of related technical skill: Historically, a major reason for failed renewable energy system projects has been the absence of know-how transfer of the new technology to individuals in the communities that received them. The executors of new technology often overlook the need for local technical training, maintenance service expertise development, user education and awareness. Renewable energy technician training will be absolutely necessary for any renewable energy project to be successful. Builders will need education in renewable energy construction techniques and the public psyche will need to be shifted to adapt their lifestyles to a changing energy system. Trades schools, technical colleges and universities will need to be prepared and equipped to support the transition to the new energy system as well.

- Uncertainty of finance sources: Renewable energy technology is still expensive at its current stage of development, even to governments. For rural communities and individuals, the cost of owning a selfsponsored renewable energy system is simply cost prohibitive. Short of a donor-developed project by an 
NGO, an innovative financing approach will be needed to implement a renewable energy based infrastructure in the rural communities where the need is the greatest.

- Orderly implementation of the new energy systems: This is important in order to cut down on sloppy projects and - quackeryll. Typical of any newly introduced social apparatus, the excitement of new energy technology coupled with the yearning of citizens for a steady power supply is attracting a myriad of - quacksl into the renewable energy development business. One of the greatest impediments to adoption of the new energy system will be disappointed citizens who are burnt with failed renewable energy projects executed by illegitimate businesses wanting only to make a profit.

- Poor resource management and lack of commitment by various levels of government to invest in energy development are also real challenges that may mitigate a successful implantation of any sustainable energy technology. When resources are transformed and managed properly they are capable of providing fountains of prosperity. However, when mismanaged, they are equally capable of producing mountains of misery to the society.

\section{RENEWABLE ENERGY TECHNOLOGIES}

Renewable energy technologies (RETs) can be deployed to produce marketable energy by converting natural phenomena into useful forms of energy. These technologies use the sun's energy and its direct and indirect effects on the earth (solar radiation, wind, falling water and various plants, i.e. biomass), gravitational forces (tides), and the heat of the earth's core (geothermal) as the resources from which energy is produced. These resources have massive energy potential, however, they are generally diffused and not fully accessible, most of them are intermittent, and have distinct regional variability (Bazmia and Zahedia, 2011). Nowadays, significant progress is made by improving the collection and conversion efficiencies, lowering the initial and maintenance costs, and increasing the reliability and applicability.

The potential role of renewable energy technologies (RETs) in transforming global energy use, with a focus on sustainable development and increasing the welfare and health of the rural poor, is enormous. Renewable energy sources, such as biomass, biogas, wind, solar, mini-hydro, geothermal, can provide sustainable energy services, using a mix of readily available, indigenous resources with potential to result in minimal local environmental damage or net emissions of GHGs. A transition to renewables-based energy systems looks increasingly desirable and possible because the costs of solar and wind power systems have dropped substantially in the past 30 years. Most forecasts indicate that costs of renewably produced electricity should continue to decline, while the price of oil and gas continues to fluctuate. If social and environmental costs are included in the estimation of electricity costs, RETs become still more attractive (Kuku, 2009).

The objectives of harnessing renewable energy (RE) as primary energy source are to focus on provision of sustainable energy to the economically subjugated fraction of the society, combat energy shortage, encourage the development of rural infrastructure and provide clean energy from the perspective of the Kyoto directive towards global decarbonization. This concept of RE has become a fast growing idea in the global power sector. The popularity of RE development can be directly allied to the growing trend of environmental concern and the rapidly depleting reserves of conventional energy resources due to the aggressive utilization. These emergent concerns call for a viable alternative solution to the contemporary environmental challenges and the energy crisis scenario through sustainable means (Albadi and El-Saadany, 2010). Perhaps the greatest challenge in realizing a sustainable future is to develop technology for integration and control of renewable energy sources in smart grid distributed generation. The smart power grid distributed energy system provides the platform for the use of renewable sources as adequate emergency power for major metropolitan load centers and the ability to break up the interconnected power systems into the cluster smaller regions.

The increasing energy demand, the rapidly depleting fossil fuel reserves and the environmental problems associated with the use of fossil fuel have necessitated the development of alternative energy sources - renewable energy sources (such as wind energy, solar energy, hydro power etc) for electricity generation in Nigeria. It is reported that the electricity generation in Nigeria as at 2015 was less than 5,000 MW due to fluctuations in the availability and maintenance of production sources, leading to a shortfall in supply (Zubairu et al., 2015). However, analyses of available renewable energy resources data for selected cities have confirmed a high prospect of renewable energy resources in Nigeria. Several studies on renewable sources of energy have also been performed.

The Nigerian Energy Commission and the Solar Energy Society of Nigeria have been tasked with generating a standalone solar-powered solution for the remote rural dwellers. The country is looking towards further development of the hydropower resources and other renewable energies such as wind, solar and biomass to close the generation shortfall and foster the economic growth. The level of utilization of Nigeria's RE resources requires serious attention to salvage the country from a looming energy crisis (Shaaban and Petinrin, 2014). 
Since the early 2000, Nigeria has identified RE as an additional source to improve electrical power generation. Presently, RE is being developed for empowering the local economies, but the RE incorporation to the national grid is yet to be implemented at a greater scale (Abdullahi et al., 2015). Nigeria is among the developing countries that is slowly striving to include RE in their future energy development. Amongst the reasons for the slow uptake in RE are high capital cost of initial financial investment as well as lack of adequate knowledge regarding the benefits of RE.

As stated earlier, in Nigeria, there is high solar irradiation and excellent wind speed that can be effectively utilized for electricity generation. To maximally benefit from these, there is a greater need for good leadership and good governance.

Many experts now argue that technologies such as solar, wind, and small-scale hydropower are not only economically viable but also ideal for rural areas. Renewable energy technologies (RETs) are cost-competitive with conventional energy sources in applications such as solar water heating, off-grid electrification with solar photovoltaics (PV), small-scale biomass power generation, biofuels, grid-connected and off-grid wind power, small hydropower, geothermal power, and methane utilization from urban and industrial waste (Painuly, 2001).

\section{Development of Renewable Energy Technologies in Nigeria}

In Nigeria as in other developing nations, the demands for sustainable energy are increasing due to population and developmental growth. But the available infrastructures for providing and extending these required energy especially to rural areas have continued to diminish and have become grossly inadequate in recent times. The realization of this fact have necessitated the need for the nation to identify and promote the development and utilization of other renewable energy sources such as wind, small or mini hydropower sources to augment the existing ones for the socio-economic development of the unreached rural areas of Nigeria (Otuna et al., 2012).

Recently, modern and efficient technologies have been used to develop and adopt devices for the utilization of renewable energy resources by the following Research Centres of the Energy Commission of Nigeria:

- Center for Energy Research and Development, Obafemi Awolowo University, Ile-ife, Osun State;

- Centre for Energy Research and Training, Ahmadu Bello University, Zaria, Kaduna State;

- National Centre for Energy Research and Development, University of Nigeria, Nsukka, Enugu State;

- Sokoto Energy Research Center, Usman Dan-Fodio University, Sokoto, Sokoto State.

The Centres at Ile-Ife and Zaria work on peaceful application of Nuclear Science and Technology while those at Nsukka and Sokoto work on solar energy and other renewable energy sources.

Raw materials used for some of these devices have more than $90 \%$ local contents. Some of these appliances include:

- Solar Crop Dryers (such as the 2 tonne capacity Rice Solar Dryer at Agbani, Enugu State and 2 tonne capacity Forage Solar Dryer at National Agricultural Production Research Institute, Ahmadu Bello University, Zaria, Kaduna State), which can be used to process agricultural products such as rice, maize, pepper, tomatoes, cocoa, tea, and coffee;

- Solar Water Heaters for providing hot water in hotels and hospitals for bathing and washing, such the 1000 litre capacity Solar Water Heater at the maternity ward of Usman Dan-Fodio University Teaching Hospital, Sokoto, Sokoto State;

- Solar PV Water Pumping for clean potable water, such as the 7.2k Wp Solar PV Plant at Kwalkwalama in Sokoto, the 2.85kWp Solar PV Plant at the centre for mentally-ill Destitutes at Itumbuzo in Abia State and the 5.00kWp Solar PV Plant at Comprehensive Health Centre in Laje, Ondo State;

- Biogas Plants for cooking gas and bio-fertilizer, such as the $20 \mathrm{~m} 3$ Biodigester at Ifelodun Cooperative Farm at Agege, Lagos State, the $10 \mathrm{~m} 3$ biogas plant at Achara in Enugu State and the $30 \mathrm{~m} 3$ biogas plant at Zaria Prison in Kaduna State; and 5kWp wind power plant at Sayya Gidan Gada in Sokoto State;

- The Energy Commission of Nigeria, the defunct Power Holding Cooperation of Nigeria and MTNNigeria are collaborating with the World Bank on a bio-fuel for rural electrification project in Nigeria. The bio-fuel is to be sourced from Jatropha Plant or any economically viable energy crop on a long term basis. Similarly, the Energy Commission of Nigeria signed another MOU with Green Shield of Nigeria (a registered NGO with diversed interest in alternative energy sources etc) to produce bio-diesel as a renewable energy for domestic and commercial uses in Nigeria, using Jatropha plant.

- The Renewable Energy Programme office, Adamawa State Government and Green Carbon Afrique is developing sugarcane based biofuel plants in Girei and Demsa Local Government Areas of Adamawa State covering 2,000 hectares of plantations. This initiative is to produce sugar for local use and export, ethanol and ultimately electricity. This integrated project is being replicated in ten states of the country.

- Currently, rice production and processing in Nigeria is typically undertaken by small local farmers using basic processing technology. Typical issues limiting economies of large-scale rice production include lack 
of access to improved technologies, the high costs of energy for parboiling, and lower output quality (post processing). However, working in conjunction with Carbon Quest and Adamawa State, the Renewable Energy Programme office is establishing an integrated "Rice Processing and Power Generating Facilitator", to the economic benefit of the investing state, garnering the advantages of large-scale rice production and self-generated power from the rice husks.

As pointed above, there have been a number of pilot projects in renewable energy in Nigeria. However, so far very few initiatives have been scaled up or replicated. In the following section we highlight some of the key challenges that practitioners have identified in facilitating local energy provision in low-income communities in Nigeria.

\section{Barriers to Penetration of Renewable Energy Technologies in Nigeria}

Despite technological developments and economic viability for several applications, renewable energy sources have been tapped only to a small fraction of its potential in Nigeria. This is due to the existence of several types of barriers to the penetration of renewable energy. Among these barriers are:

\section{Policy and Regulatory Barriers}

The focus of national policy has consistently been on centralized conventional sources of electric power. Several incentives were established to promote investments in conventional power generation. Subsidizing grid power has so far penalized investments in alternative energy solutions. This lack of a level playing field for all energy sources and technologies has constituted a formidable barrier to the growth of alternative electricity services.

Until lately, the defunct Power Holding Company of Nigeria (PHCN) was the only entity legally permitted to produce and distribute electricity. Under the 2005 Act, independent power producers are permitted to operate, however, the legal framework for successfully implementing PPA is still evolving. The perception of significant regulatory risks by potential investors and financial institutions compound the challenges faced by potential renewable electricity investors. Moreover, guaranteed access to the grid is an important element of an investment decision to embark on grid-connected power projects. At present, a non-discriminatory open access to the national electricity grid, for renewable power, is not assured.

\section{Financing and Investment Bartiers}

Renewable energy projects have high initial costs. This affects the overall cost of energy produced per kWh. Investors will not be favorably disposed to wind, small hydro or power from cogeneration plants if they will not make profit by selling the electricity. Average electricity tariff in Nigeria is put at about N6.75 per KW-h (approximately 5 cents per $\mathrm{kWh}$ ). Average cost of typical sources of renewable power for mini hydro is 5-10 cents; solar PV: 20 -40 cents; biomass power: 5-12cents; wind power: $6-10$ cents. Without adequate financial incentives market entry will be difficult.

Renewable electricity projects are not common practice, therefore bankers perceive a higher degree of risk and are reluctant to lend - instead they give preference to large-scale conventional electricity investments. Interest rates are generally high and the appetite for long term credits are low among financial institutions, especially for nonbusiness-as-usual projects as small scale renewable power projects.

Nigeria has no significant manufacturing capacity for components of renewable energy technologies. The existing capacity in solar PV and small hydro plants is limited. Significant supply chain constraints include long project implementation periods, high import tariffs, bottle-necks in the customs clearing of goods and the issue of corruption.

\section{Technological Barrier}

As noted in the 2005 National Renewable Energy Master Plan supplies and servicing for renewable electricity projects are not readily available in Nigeria. Therefore, potential IPPs may face significant logistical challenges in procuring equipment and maintenance support for renewable electricity projects.

Beyond the local availability of supplies, there are significant gaps in the capacity for manufacture and maintenance of system components such as small hydro and wind turbines. In most cases, the choice and design of turbines are site-specific. With no local turbine manufacturers available in Nigeria, this adds to project complexity and costs. The simple fact that the project will be dependent on manufactures of the turbines for spares and major maintenance presents a major technical challenge. To compound these barriers, these projects are often located in remote areas and therefore face significant challenges in attracting competent and qualified manpower for operations.

\section{Limited Public Awareness}

There is limited public awareness of the potentials of renewable electricity in meeting some of the energy and development challenges facing the country. The inadequacy of awareness creates a market distortion which results 
in higher risk perception for potential renewable electricity projects. The general perception is that these forms of energy technologies are not mature and only suited for niche markets.

\section{Standards and Quality Control}

A major constraint to the development of the renewable energy market in Nigeria is the poorly established standard and quality control of locally manufactured and imported technologies. Creating quality assurance is a precondition for building consumer confidence and in growing the market for renewable energy. Two important dimensions to issues of quality include the perception of potential users, poorly developed regime for standards setting, testing and certification as well as professionalism among operators.

\section{Inadequate Resource Assessment}

The growth of the renewable power industry will depend to a large extent on the availability of a solid resource database. Reliable and up-to-date sources of data will assist investors in making decisions on renewable electricity in the country.

\section{Intermittency of Resource Availability}

An underlying barrier affecting all renewable electricity resources is the intermittency of their availability. The challenge of energy storage and system management presents a major challenge and adds to the complexity and costs of renewable electricity.

The Policy Guideline establishes a framework to address the above barriers. It creates measures that enable market expansion and private sector participation in renewable electricity business. It further facilitates gridconnected and off-grid operations as well as increased role for renewable electricity in rural electrification.

\section{Decentralized Renewable Energy System}

Energy will always be at the forefront of growth and development. Nigeria's renewable energy potentials are too promising to be ignored. With projections estimating Nigeria's fossil fuel reserves to be depleted to an uneconomical point by 2050 (Shaaban and Petinrin, 2014), more than ever the time to pay close attention to decentralized renewable energy generation is now.

Presently, most of the power received by Nigerian electricity consumers is central (on-grid) power supplied by the Distribution Companies (DISCOs). On-grid power generation has over the years had its constraints, some of which are: unavailability of gas, inadequate transmission infrastructure, liquidity issues in the Nigerian Electricity Supply Industry (NESI), non-completion of Nigerian Integrated Power Project (NIPP) Plants etc. It is imperative to note that whilst the issues raised above are being resolved, Nigeria has to look at viable solutions for increasing access to electricity in the country through decentralized energy system.

The use of decentralized renewable electricity is a promising way to meet the demand for basic energy needs in Nigeria, especially among the rural dwellers. Such systems - which include, for example, solar home systems, small wind and mini-hydro, and portable solar lanterns - do not require installation of costly transmission lines and are becoming increasingly affordable to improved economies of scale as a result of the growing number of users and technical improvements (WADE, 2009). In addition, decentralized systems are more likely to be manufactured and/or repaired locally and are hence, less dependent on foreign technical assistance, strengthening the sustainability of rural livelihoods (Oyedepo, 2014a).

Considering Nigeria's plans to increase generation capacity in the coming years and the low level of access to electricity in the rural areas; there is need for significant investments in decentralized (off-grid) energy system generation. Among the prospects of decentralized renewable energy system solutions in Nigeria include the following:

Potential to grow industrial clusters and small cottage industries: Most industrial clusters and some small cottage industries require uninterrupted power supply to function optimally. The power supplied could be generated through fully decentralized renewable power plants or embedded within distribution networks. This could potentially transform the economy of these areas; increase profitability for the existing businesses; create jobs; and breed a crop of customers who are willing to pay for electricity supplied. In view of this, the Manufacturers Association of Nigeria (MAN) has identified about 28 clusters for mini-grid modular plants ranging from 5 to $50 \mathrm{MW}$ in areas including Ogun and Lagos States (www.thisdaylive.com).

Opportunity to expand and refurbish distribution networks of the DISCOs: In line with the NERC Regulation for Independent Electricity Distribution Networks, 2012 (IEDN Regulations), decentralized renewable generation plants require Independent Electricity Distribution Networks (IEDNs) to supply electricity to end users, save for eligible customers upon declaration by the Minister of Power, who can be supplied to directly. This creates opportunities for investors who may wish to create off-grid projects with their own IEDN. This could potentially be a win-win situation for DISCOs who could either collaborate with developers to expand or refurbish 
European Journal of Sustainable Development Research, 2(4), 40

Table 6. Summary of Renewable Energy Targets

\begin{tabular}{lllll}
\hline $\mathbf{S} /$ No & Source & Short Term & Medium Term & Long Term \\
\hline 1 & Large Hydropower & 1930 & 5930 & 48,000 \\
\hline 2 & Small Hydropower & 100 & 734 & 19,000 \\
\hline 3 & Solar PV & 5 & 120 & 500 \\
\hline 4 & Solar Thermal & - & 1 & 5 \\
\hline 5 & Biomass & - & 100 & 800 \\
\hline 6 & Wind & 1 & 20 & 40 \\
\hline 7 & All Renewable & 2036 & 6905 & 68,345 \\
\hline 8 & All Energy Sources & 16,000 & 30,000 & 192,000 \\
\hline 9 & \% of Renewable & $13 \%$ & $23 \%$ & $36 \%$ \\
\hline
\end{tabular}

Source: Obideyi (2017); Idemudia and Nordstrom (2016)

their network; add to their number of paying customers; or acquire the developer assets given the right regulatory framework.

Opportunity to collaborate with State Governments: Many state governments are looking to partner with investors to develop more decentralized (off grid) projects than on-grid projects. This may be to avoid regulatory constraints (as a result of the fact that most laws, regulations, and agencies for on-grid projects are controlled by the federal government) which state governments may experience when executing on-grid projects. It must, however, be noted that whilst these constraints may be minimal with off-grid projects, they cannot be totally avoided, as NERC, being the regulator of the power sector still has the power to issue off-grid licenses and generally regulate the power sector. Notably, the Lagos State Government has initiated some Independent Power Projects (IPPs) to provide electricity to its own establishments, including schools, ministries, hospitals, and courts. As at July, 2015, the state had commissioned five IPPs with an accumulated capacity of 47.5MW.

Access to other fuel alternatives: Most of the power plants in Nigeria are gas fired thermal plants.

Given the current constraints with gas, decentralized renewable power plants are able to take advantage of diverse and hybrid fuel sources like renewables (solar, wind, biomass) and because the power is not generated on grid, transmission constraints with renewables are eliminated. This would be particularly more useful in areas where there is limited gas supply, e.g. the northern part of Nigeria where solar, wind, and hydro sources are prevalent.

Considerable insulation from the issues within the NESI: Given Nigeria's considerable power requirements, decentralized energy system solutions within a cluster of customers willing and able to pay present a viable investment opportunity for power developers. This is particularly because their investment would be insulated from the current liquidity issues in the NESI.

Opportunity for rural electrification: Decentralized energy system solutions are also useful in Nigeria in view of some topographical or geographical challenges in the rural areas which have made it uneconomical to extend the grid to such areas. Rural electrification in Nigeria is currently in a weak and dilapidated state; hence there is a dire need for investments. It is expected that many rural electrification projects will spring up this year. A priority for the renewable energy agency (REA) should be the sustainable development of rural mini-grids that are targeted towards the economic development of these rural communities so that the communities can learn the culture of paying for electricity.

\section{Policies and Renewable Energy Resources Initiatives}

Renewable energy deployment in Nigeria is still at its infancy stage. Apart from hydropower no grid connected capacity has been installed yet; however, plans were put in place to have grid connected renewable energy power from 2017 on (Sambo, 2018). One of the reasons that explain this is the lack of policies and regulatory framework that drives the sub-sector in the past. Large scale implementation process of renewable energy requires strategies that allow for a number of factors including priority or target setting, policy continuity and a clear focus on key issues.

The Renewable Energy Master Plan (REMP) principally aims to improve the development of renewable energy and eliminate obstacles that hinder this goal. It amplifies the framework, targets and timelines of specific renewable energy sources which include solar energy, hydropower, biomass and wind. The main objective of this plan is to promote national energy security, improve energy access especially in rural areas and encourage research and development of renewable energy in Nigeria. The objectives are to be achieved short-term (2015 -2020), medium term (2020 - 2025) and long-term (2025-2030) and the programmes include: National Biomass Energy Programme, National Solar Energy Programme, National Hydropower Programme, National Wind Energy Programme, Emerging Energy Programme and Framework Programme for Renewable Energy Promotion (Obideyi, 2017). A summary of the renewable energy targets is shown in Table 6.

Although, the nationwide potential for large-scale Renewable Energy projects is immense, existing large-scale grid connected renewable energy projects do mainly exist as large hydropower dams. To date, no real commercial large-scale project has been successfully implemented, other than hydropower (Adebisi and Yabo, 2016). Many 
Federal and state Government Ministries, Department, and Agencies (MDAs) as well as private sector players have organized programmes to support and implement various renewable energy technology projects in the near future.

Some of the goals for renewable energy sources include: to attain $15 \%$ and $20 \%$ contribution of hydro to the nation's electricity mix by 2015 and 2020 respectively, attain 1\% contribution of wind and solar respectively to the electricity generation mix by 2020 , ensure replacement of $50 \%$ of firewood consumed with biomass energy technology by 2020 and utilize biomass resource to obtain power generation capacity of 1000MW.

There is however evidently slow integration of renewable energy into the energy mix despite its abundance in the nation. .Numerous projects are planned/ongoing for the improvement of energy accessibility in Nigeria. Recently, the Federal Government was involved in some partnership with private sectors to provide both on-grid and off-grid solar solutions. In July 2016, license was granted to 14 solar developers (Quaint Abiba Power Ltd, Anjeed Innova Group, Nova Scotia Power Development Company, Pan African Solar, Nigerian Solar Capital Partner, Afrinergia Power Ltd, Motir Dusable Ltd, Nova Solar 5 Farm Ltd, Kuk Power Ltd, Middle Band Solar One Ltd, LR Aaron Power Ltd, CT Cosmos, EN Africa, Oriental Renewable Solution) to include solar to the national grid and the Nigerian Bulk Electricity Trading (NBET) signed the first solar Power Purchase Agreement (PPA) with these developers to produce a total of 1125 MW of utility-scale solar (Obideyi, 2017; Detail Commercial Solicitors, 2018). Also a national Solar Home System Program (SHS) was recently introduced in alliance with the NDPHC and Azuri technologies (a private mobile pay-go systems specialist); the goal is to provide 20,000 homes with off-grid solar power systems within a period of 12 months (initial phase) (Ofikhenua, 2017). This solution is targeted towards rural areas that lack access to the grid, it aims to stimulate social and economic activities by ensuring affordability through a monthly repayment scheme; about 200 units were deployed at the pilot phase in Wuna, a rural village on the outskirts of Abuja. A full-scale rural electrification project commenced in 2011 and funded by United States Agency for International Development (USAID) and United States Department of energy; had a total funds invested of $\$ 450,000$ (Okereke, 2017). The project provided a water pumping system, street lighting, a microenterprise center, light for 20 homes, and portable pump for crops as well as power to healthcare centers, schools and religious centers in Jigawa state. The project was implemented and is being maintained by Solar Electric Light Fund (SELF), an NGO located in Washington, DC. Recently, NBET signed PPAs to procure 1,200 MW of solar power at the rate of 11.5 US cents/kWh expected to come online by 2018 (Sambo, 2018).

The first wind farm project in Nigeria was awarded in 2010 with expected completion in 2012. It is a 10MW farm located in Katsina and it is worth 5.5billion Naira (Saddik \& Alhassan 2012). As at 2016, only about 5 wind turbines of 37 expected units have been mounted; each turbine was installed at a height of $55 \mathrm{~m}$ and has a generation capacity of about $275 \mathrm{~kW}$ (Sunday, 2016).

As regard hydropower projects, Federal Government is making attempts to construct both large hydropower (LHP) and small hydropower (SHP) plants. The biggest of these projects for the LHP power plant is the $3050 \mathrm{MW}$ Mambilla project in Taraba state. The project was initiated in 1972. The Federal Executive Council (FEC) on the 30th August 2017 approved the contract for the engineering work in the sum of $\$ 5,792 \mathrm{bn}$. The project is expected to be completed within 6 years (Detail Commercial Solicitors, 2018). According to Akorede et.al (2017), the government also signed a contract worth $\$ 1.293$ billion for the construction of $700 \mathrm{MW}$ plant in Zungeru and constructions have started.

Renewable energy utilisation in Nigeria is becoming a top priority on the policy agenda. Before now renewable energy utilization is limited to large hydro power which contribute about $20 \%$ of the electricity mix. However, at present a lot of attention is given to other renewable energy resource development such as solar, wind, small hydro and biomass. The total share of new renewable energy in total energy and electricity mix is still very low, but this is expected to increase as the gains from the recent power market reforms starts to trickle in (Sambo, 2018).

In May 2015, the Nigerian Federal Executive Council approved the National Renewable Energy and Energy Efficiency Policy (NREEEP). The NREEEP outlines the national thrust of the policy and measures for the promotion of renewable energy and energy efficiency (Lawal and Ojo, 2017). The NREEEP projects off grid power generation from renewables to reach an estimated 12,500 MW in 2030. Nigeria intends to increase generation capacity using renewable energy sources including solar, wind and hydro with capacities of $1345 \mathrm{MW}$, $631 \mathrm{MW}$ and $6156 \mathrm{MW}$, respectively.

\section{RECOMMENDATIONS FOR THE WAY FORWARD IN ACHIEVING SUSTAINABLE ENERGY}

Based on the benefits of renewable energy systems, the following recommendations are suggested key to moving forward on large-scale deployment of renewable energy technologies in Nigeria: 


\section{Establishing a Legal and Regulatory Framework}

All the objectives listed in the Power Sector Reform programme, if fully implemented, will help solve the energy poverty issue in Nigeria. NERC must monitor the activities of all participants in the electricity market and ensure that all rules, regulations, and codes are enforced in a fair, transparent and equitable way. It is also crucial to institutionalize and improve the relevant legal and administrative framework, including establishing a serious commitment to developing and enforcing standards, regulations and codes for Renewable Energy Technologies and Systems (RET/RES). NERC also has to ensure that each energy sector decision will be in the public interest.

\section{Adoption of Feed - in Tarrifs Scheme}

Several countries have adopted feed-in tariffs, public competitive bidding (tendering), tax incentives, and quotas to drive deployment of renewable energy system. The use of public competitive bidding has gained momentum in recent years, with Brazil, El Salvador, Peru, and Uruguay issuing tenders in 2013 for more than 6.6 GW of renewable electric capacity. Japan for example implemented the solar Feed in Tariff (FIT) scheme that began in November 2009 and this has played an essential role in the recent strong growth in solar PV installations. According to the program, utilities are required to purchase surplus solar electricity for ten years at a fixed rate of JPY48 (USD 0.60)/kWh-almost twice as high as the market price of electricity—for residential PV installations below $10 \mathrm{~kW}$ (Wei-Ming et al., 2014). The FIT program has been very successful; according to Ministry of Economy Trade and Industry (METI) (2014), the annual surplus solar electricity purchased by the utilities reached 1.4 billion $\mathrm{kWh}$ in 2010. At the end of 2011, Japan had the third largest solar PV capacity in the world after Germany and Italy, with an installed capacity of 4.9 GW (European Photovoltaic Industry Association, 2012). Nigeria can take a cue from this.

\section{Fiscal Support}

The provision of fiscal incentives can address financial barriers to the development of renewables (Emodi and Ebele, 2016). Fiscal support can come in various forms which may be from tax exemptions on imported RE equipment, to tax holidays on generation incomes (KPMG, 2011). Some tax incentive policies includes; import duty/excise duty concession, VAT concession, tax credit, production tax concession, and tax holiday on generation income. Furthermore, environmental taxes have proved to be an effective fiscal support in some countries. An example is observed in Denmark which was one of the first European Union countries to implement an environmental tax. Since 1992, Denmark energy consumers have been charged a $\mathrm{CO}_{2}$ tax and some of the revenue generated goes to generators of electricity from renewable energy (Fouquet and Johansson, 2005). Another country is Sweden which used the same approach and this added in the expansion of biomass. This made energy from fossil fuel such as coal very expensive (Joelsson, 2011).

\section{Regular Evaluation of Existing Energy Policy and Plans}

The government should plan to review, periodically assess and evaluate the existing National Energy Policy, Renewable Energy Master Plan, Solar PV Master Plan, Energy Master Plan, and Renewable Electricity Master Plan.

\section{Increased National Awareness}

In order to create awareness of new energy sources, research into Renewable Energy Technologies and Systems should be promoted nationally, as should news about their development, uses, deployment and dispersal. Disseminating information about new energy sources, drawing up public awareness strategies and Consumer Consultation Services will also be important.

\section{Investment and private sector involvement}

Speeding up DE deployment in Nigeria requires huge investment that exceeds the current capability of the domestic private sector. So far, foreign investment capital and national foreign exchange earnings have funded energy sector investment. Introducing new market incentives, along with fiscal and regulatory measures at the national and local Government levels, could encourage more private investment in the power sector. In addition, feed-in tariffs (see glossary) could stimulate the private sector to invest in DE technology and make DE viable.

\section{Technological and Environmental Support}

In order to support the development of RE, the technological and environmental support needs to be explored. For technological aspect, R\&D support comes in mind. Most R\&D programs are typically in the form of grants or loans and sometimes provided with no expectations of financial gains. However, it is very important that the particular R\&D program receiving the funds for the R\&D develops patentable technologies. In Australia, the government competitive grant scheme called the Renewable Energy demonstration Programs (REDP) was used to support the development of commercial RE projects and mini-grid project (Hogg and O'Regan, 2010). The 
German Federal Ministry of Economic Cooperation and Development (BMZ) commissioned the Renewable Energy Support Programme for ASEAN (RESP-ASEAN) to enable the sharing of expertise and policies in order to improve framework conditions for RE in ASEAN countries. This produced corresponding guidelines for bioenergy projects in Indonesia bioenergy project and Philippines solar project (ASEAN-RESP, 2015).

\section{Renewable Portfolio Standards}

Considered as the least-cost option for RE development in many countries, RPS has a reputation for bringing down the cost of RE technologies and it creates a competitive market. The RPS system has shown in many countries to be a sustainable policy to RE generators since the government will compensate them for their extra costs through subsidies. This option if considered by the Nigerian government has the potential to create a RE market in Nigeria that will be very competitive since Nigeria have the market and large RE resource potential. However, the Nigerian government should ensure the flexibility of targets and adjust it on the short-term bases. The government should also take note of regional imbalance in pricing as some locations may have higher RE resource potential than others, while some may have the problems of electricity transmission and distribution.

\section{International Cooperation}

Developing international cooperation is important, especially in the areas of developing local RETs and RES manufacturing capacity and Smart Grid systems that can enable grid stability when RE electricity is injected.

\section{Education and Training}

The government, together with educational institutions, should establish education and training in RETs and RES to develop the skills and knowledge of technicians, engineers, administrators, and other key staff.

\section{CONCLUSION}

This study examines the appropriateness of utilizing available renewable energy sources in Nigeria, namely solar energy, wind energy, small hydro power and biomass in form of decentralized energy system to provide electricity in rural areas and urban locations not connected to the national grid. Decentralized energy system has been shown to offer substantial advantages over conventional power generation in Nigeria. This remains true across a range of areas, including the environment, the economy, efficiency, security and reliability, as outlined in this paper.

Current energy policy is not suitable for sustainable economic growth in Nigeria. Since current centrally managed systems have completely failed to address the nation's energy problem, a decentralized energy system based on possible future re-structuring of a Federal Nigeria is discussed. Only decentralized energy systems in which users are involved in planning, development, construction, operation, and maintenance, are sustainable in the long-term. Decentralized energy projects are small in size but more efficient, and can avoid major environmental, social disturbances, and foreign investment associated with large-scale centrally managed energy systems.

Estimated total investments to meet the demand for the Optimistic Growth Scenario is US\$ 484.62 billion. The Federal Government alone cannot provide this level of funding. Indeed, the state governments, private sector and foreign investors must be involved. Moreover, all the country's energy resources and more importantly, renewable energy need to be deployed in order to achieve matching supply with demand on a continuous basis.

The economic and social opportunities that sustainable energy systems can bring are significant attractions for various private and federal organizations in Nigeria to invest aggressively in the new systems. However, an orderly adaptation process to the new energy system must be followed. This includes:

(a) Identification of solar powered electric energy, small hydro-power system and biogas generation through biomass technology development as systems enterprises that will create maximum benefit at the grassroots level in both the rural and urban communities of Nigeria;

(b) Prioritization of the need to modify the current energy generation and distribution monopoly in Nigeria and allow decentralized investment and development of sustainable energy systems;

(c) Creation of a triad joint research synergy between a foreign research institution, two or more research institutions in Nigeria and a renewable energy development professional who will bring about the execution and implantation of research results into practice;

(d) Identification of the distributed social infrastructures that will benefit from the identified sustainable energy sources; and

(e) Development of financing models that will help stimulate sustainable energy development and make it affordable to citizens. 


\section{REFERENCES}

Abam, F. I., Nwankwojike, B. N., Ohunakin, O. S. and Ojomu, S. A. (2014). Energy Resource Structure and Ongoing Sustainable Development Policy in Nigeria: A Review. International Journal of Energy and Environmental Engineering, 5(2), 2-16. https:// doi.org/10.1007/s40095-014-0102-8

Abam, F. I. and Effiom, S. O. (2015). Evaluation of Intensity and Structural Effects on Energy Consumption Trend in Nigeria Using the 3-D Decomposition Model. International Journal of Engineering \& Technology Sciences, 3(16), 372-381.

Abdullahi, A. M., Asan, V. W., Firdaus, M. S., Ibrahim, A. M., Abu, B. M. and Norhidayah, M. Y. (2015). An assessment of renewable energy readiness in Africa: Case study of Nigeria and Cameroon. Renewable and Sustainable Energy Reviews, 51, 775-784. https:/ / doi.org/10.1016/j.rser.2015.06.045

Adebisi, A. and Yabo, F. Y. (2016). Sustainable Energy for All Action Agenda (SE4ALL-AA). National Council on Power (NACOP), Abuja, Nigeria, 1-104.

Adegbulugbe, A. O. (2007). Balancing the Acts in the Power Sector: The Unfolding Story of 188 Nigeria Independent Power Projects. Presented at the 2007 27th USAEE/ IAEE North American Conference. Available at: http://www.usaee.org/usaee2007/submissions/OnlineProceedings/AS\%20Momodu\%20Paper.doc

(Accessed 29 April 2009)

Adaramola, M. S. (2012). Feasibility Study of Off-grid Hybrid Energy Systems for Applications in Ondo State Nigeria. Journal of Engineering and Applied Sciences, 7(1), $72-78$.

Adaramola, M. S., Oyewola, O. M. and Paul, S. S. (2012). Technical and economic assessment of hybrid energy systems in South-West Nigeria. Energy Exploration \& Exploitation, 30(4), 533-552. https://doi.org/10.1260/0144-5987.30.4.533

Adaramola, M. S. and Oyewola, O.M. (2011). Wind speed distribution and characteristics in Nigeria. ARPNJ. Eng. Appl. Sci., 6(2), 82-86.

Adem, A., Murat, İ. K., Murat, K., İsmail, H. Ö. and Kamil, K. (2008). Energy situation and renewables in Turkey and environmental effects of energy use. Renewable and Sustainable Energy Reviews, 12(8), 2013-2039. https://doi.org/10.1016/j.rser.2007.04.011

Agba, A. M., Ushie, M. E., Abam, F. I., Agba, M. S. and Okoro, J. (2010). Developing the Biofuel Industry for Effective Rural Transformation. European Journal of Scientific Research, 40(3), 441.

Agbetuyi, A. F., Akinbulire, T. O., Abdulkareem, A. and Awosope, C. O. (2012). Wind energy potential in Nigeria. International Electrical Engineering Journal, 3(1), 595-601.

Agbro, E. and Ogie, N. (2012). A Comprehensive review of Biomass Resources and Biofuel Production Potentials in Nigeria. Research Journal in Engineering and Applied Sciences, 1(3), 149-155.

Ajao, K. R., Ajimotokan, H. A. and Popoola, O. T. (2009). Electric Energy Supply in Nigeria, Decentralized Energy Approach. Cogeneration and Distributed Generation Journal, 24(4), 34-50. https://doi.org/10.1080/15453660909595149

Albadi, M. H. and El-Saadany, E. F. (2010). Overview of wind power intermittency impacts on power systems. Electric Power Systems Research, 80, 627-632. https://doi.org/10.1016/j.epsr.2009.10.035

Ali, E. (2011). The Transfer of Sustainable Energy Technology to Developing Countries: Understanding the Need of Bangladesh. Energy Science and Technology, 1(1), 94-109.

ASEAN-RESP. (2015). Renewable energy in South-East Asia. Available at: https://www.giz.de/en/worldwide/16395.html

Bajpai, P. and Dash, V. (2012). Hybrid renewable energy systems for power generation in stand-alone applications: A review. Renewable and Sustainable Energy Reviewss, 16, 2926- 2939. https://doi.org/10.1016/j.rser.2012.02.009

Bazmia, A. A. and Zahedia, G. (2011). Sustainable energy systems: Role of optimization modeling techniques in power generation and supply-A review. Renewable and Sustainable Energy Reviews, 15, 3480-3500. https://doi.org/10.1016/j.rser.2011.05.003

CBN. (2012). Central Bank of Nigeria statistical bulletin 2012. Available at: http://www.cenbank.org/document/statbulletin (Accessed Jan 2013).

CIA World Factbook, Nigeria. (2014). Available at: https://www.cia.gov/library/publications/the-worldfactbook/geos/ni.html (Accessed 17 July 2016)

Detail Commercial Solicitors. (2018). Nigerian Power Guide Volume 4, 2018 Edition, Lekki Phase 1, Lagos Nigeria, 1-46.

Doukas, H., Karakosta, C. and Psarras, J. (2009). RES technology transfer within the new climate regime: a 'helicopter' view under the CDM. Renewable and Sustainable Energy Reviews, 13(5), 1138-1143. https://doi.org/10.1016/j.rser.2008.05.002

Energy Commission of Nigeria (ECN). (2013). Renewable Energy Master Plan, Abuja, Nigeria. 
Eleri, E. O. and Onuvae, P. (2011). Low-Carbon Africa: Leapfrogging to Green Future: Low Carbon Nigeria. Available at: http://www.christainaid.org.uk/resources/policy/climate/low-carbon-africa.aspx (Accessed 18 July 2015)

Eleri, E. O., Ugwu, O. and Onuvae, P. (2012). Expanding access to pro-poor energy services in Nigeria. Abuja, Nigeria: International Center for Energy, Environment and Development.

Emodi, N. V. and Boo, K. (2015). Sustainable Energy Development in Nigeria: Overcoming Energy Poverty. International Journal of Energy Economics and Policy, 5(2), 580-597.

Emodi, N. V. and Yusuf, S. D. (2015). Improving Electricity Access in Nigeria: Obstacles and the Way Forward. International Journal of Energy Economics and Policy, 5(1), 335-351.

Emodi, N. V. and Ebele, N. E. (2016). Policies Promoting Renewable Energy Development and Implications for Nigeria. British Joumal of Environment \& Climate Change, 6(1), 1-17. https://doi.org/10.9734/BJECC/2016/24628

Emodi, N. V. and Ebele, N. E. (2016). Policies Promoting Renewable Energy Development and Implications for Nigeria. British Journal of Environment \& Climate Change, 6(1), 1-17. https://doi.org/10.9734/BJECC/2016/24628

Enibe, S. O. and Odukwe, A. O. (1990). Patterns of Energy Consumption in Nigeria. Energy Conversion and Management, 30(2), 69-73. https:// doi.org/10.1016/0196-8904(90)90015-Q

Esan, A. A. (2003). Preparedness on Development Green Energy for Rural Income Generation-Nigeria’s Country. Paper UNIDO, INSHP/IC SHP, Hangzhou, China June 19-23, 2003.

European Photovoltaic Industry Association. (2012). Global Market Outlook for Photovoltaics until 2016. Available at: http://www.epia.org/home (Accessed 30 June 2014).

Federal Ministry of Power (FMP). (2015). Federal Ministry of Power: National Renewable Energy and Energy Efficiency Policy (NREEEP) for the Electricity Sector (May 2015), Abuja, Nigeria.

Fouquet, D. and Johansson, T. (2005). Energy and environmental tax models from Europe and their link to other instruments for sustainability: policy evaluation and dynamics of regional integration. In Presentation at the Eighth Senior Policy Advisory Committee Meeting, Beijing, China.

Garba, N. A. and Zangina, U. (2015). Rice straw \& husk as potential sources for mini-grid rural electricity in Nigeria. Int. Journal of Applied Sciences and Engineering Research, 4(4), 523 - 530.

GIZ. (2015). Hydro Power Potential Assessment for Partner States, Abuja, Lagos.

Heider, C. Taylor-Dormond, M., Gaarder, M., Atur, V. and Jammi, R. (2015). World Bank Group Support to Electricity Access, FY2000-FY2014, World Bank.

Hepbasli, A. (2008). A key review on exergetic analysis and assessment of renewable energy resources for a sustainable future. Renewable and Sustainable Energy Reviews, 12, 593-661. https://doi.org/10.1016/j.rser.2006.10.001

Hogg, K. and O'Regan, R. (2010). Renewable energy support mechanisms: An overview. PricewaterhouseCoopers LLP, Globe Law and Business.

IAEA/ECN. (2007). Assessment of Energy Options and Strategies for Nigeria: Energy Demand, Supply and Environmental Analysis for Sustainable Energy Development (2000-2030).

Idemudia, I. G. and Nordstrom, D. B. (2016). Nigerian Power Sector: Opportunities and Challenges for Investment in 2016. Number 1930, 1 - 15, Latham \& Watkins, Lagos, Nigeria.

International Atomic Energy Agency (IAEA). (2009). IAEA Tools and Methodologies for Energy System Planning and Nuclear Energy System Assessments. Department of Nuclear Energy, Austria, 1-36.

IEA. (2007). Energy Poverty Action Initiative, Brochure. Paris, France: International Energy Agency.

IEA. (2013). Key World Energy Statistics, Paris, France.

IEA. (2014). World Energy Outlook, Paris, France.

Ismaila, H. Z. (2006). Hydro Power Resources in Nigeria. Being a country position paper presented at the 2nd Hydro Power for Today Conference International Centre on Small Hydro Power (IC-SHP), Hangzbou, China.

Iyke, B. N. (2015). Electricity consumption and economic growth in Nigeria: A revisit of the energy-growth debate. Energy Economics, 51, 166-176. https://doi.org/10.1016/j.eneco.2015.05.024

Joelsson, J. (2011). On Swedish bioenergy strategies to reduce $\mathrm{CO}_{2}$ emissions and oil use.

Karakosta, C., Doukas, H. and Psarras, J. (2008). A decision support approach for the sustainable transfer of energy technologies under the Kyoto Protocol. American Journal of Applied Sciences, 5(12), 1720-1729. https://doi.org/10.3844/ajassp.2008.1720.1729

Karakosta, C., Flamos, A. and Doukas, H. (2010). Sustainable energy technology transfers through the CDM? Application of participatory approaches for decision making facilitation. Int. J. Environmental Policy and Decision Making, 1(1), 1-16. https:// doi.org/10.1504/IJEPDM.2010.033908

Kela, R., Usman, K. M. and Tijjani, A. (2012). Potentials of Small Hydro Power in Nigeria: The Current Status and Investment Opportunities. Natural Gas, 9(12), 1703. 
Kok, M., Metz, B., Verhagen, J. and Rooijen, S. V. (2008). Integrating Development and Climate Policies: National and International Benefits. Climate Policy, 8, 103-118. https://doi.org/10.3763/cpol.2007.0436

KPMG. (2011). Taxes and Incentives for Renewable Energy. Energy \& Natural Resources. Available at: https://www.kpmg.com/Global/en/IssuesAndInsights/ArticlesPublications/Documents/Taxes-IncentivesRenewable-Energy-2011.pdf

Kuku, T. A. (2009). Renewable Energy for Sustainable Socio-Economic Development of the Nation, Nigeria, Keynote paper presented at the International Conference/Workshop on Renewable Energy, an option to Nigeria Energy Challenges, Covenant University, Ota, $13^{\text {th }}$ to $17^{\text {th }}$ July, 2009.

Ladan, M. (2009). Policy, legislative and regulatory challenges in promoting efficient and renewable energy for sustainable development and climate change mitigation in Nigeria. In: Proceedings of the $2^{\text {nd }}$ Scientific Conference of Assellau, University of Nairobi Nairobi. ABU Press, 23-25 Mar 2009. Nairobi, Kenya. https://doi.org/10.2139/ssrn.2336130

Lahmeyer. (2005). Wind Energy Resource Mapping and Related Works Project. Lahmeyer International, 2005, Bad Vilbel, Germany.

Lawal, D. and Ojo, T. (2017). Power Sector Report - Changing Potential to Reality. Cardinalstone Research, 1-50.

Lazarov, V. D., Notton, G., Zarkov, Z. and Bochev, I. (2005). Hybrid power systems with renewable energy sources types, structures, trends for research and development. Proceeding of International Conference ELMA, 51520.

Lorenzini, G., Biserni, C. and Flacco, G. (2010). Solar Thermal and Biomass Energy. WIT Press Ashurst Lodge, Ashurst, Southampton, SO40 7AA, UK.

Ministry of Economy. (2002). Planning of the sectors of electricity and gas development of the networks of transport 2002-2011. Madrid: Secretary of State of Energy, Industrial Development and of the Small and Medium Company. Main directorate of Power Policy and Mines.

Ministry of Economy Trade and Industry (METI). (2014). New Strategic Energy Plan, METI, Japan.

Mohammeda, Y. S., Mustafa, M. W., Bashir, N. and Mokhtar, A. S. (2013). Renewable energy resources for distributed power generation in Nigeria: A review of the potential. Renewable and Sustainable Energy Reviews, 22, 257-268. https:// doi.org/10.1016/j.rser.2013.01.020

NBS. (2009). Social Statistics in Nigeria, Abuja: National Bureau of Statistics.

NBS. (2011). National Bureau of Statistics (NBS) Annual abstract of statistics 2011. Available at: http:/ /www.nigerianstat.gov.ng (Accessed February 2015).

NERC. (2012). Nigerian Electricity Regulatory Commission Regulations for Embedded Generation 2011 January 2012).

NERC. (2015). Order No. NERC/REG/3/2015. Amended Multi Year Order Tariff (MYTO)-2.1 for the period April 1st, 2015 to December 2018, Abuja, Nigeria.

Nigerian Minister of Power, Works and Housing. (2016). Opportunities for off-grid solutions in the Nigerian power sector. Available at: http:/ /www.nipc.gov.ng (Accessed 30 June 2016).

Nnaji, C. E., Uzoma, C. C. and Chukwu, J. O. (2010). The Role of Renewable Energy Resources in Poverty Alleviation and Sustainable Development in Nigeria. Continental J. Social Sciences, 3, 31-37.

Nwanya, S. C. (1998). Modelling Energy Pattern in the Industrial Sector of Nigeria. M.Sc Project, University of Nigeria, Nsukka, Nigeria, 1-79.

Obideyi, O. O. (2017). Integrating Renewable Energy into Nigeria's Energy Mix: Implications for Nigeria’s Energy Security. Master's Thesis, Norwegian University of Life Sciences, Norway.

Odhiambo, N. M. (2014). Energy dependence in developing countries: does the level of income matter? Att. Econ. J., 42, 65-77. https://doi.org/10.1007/s11293-013-9402-2

Ogwueleke, T. (2009). Municipal Solid Waste Characteristics and Management in Nigeria. Iranian Journal of Environmental Health Science and Engineering, 6(3), 173-180.

Okafor, F. N. (2017). Improving Electric Power Sector Performance: The Role of Nigeria Electricity Regulatory Commission. Nigerian Academy of Engineering 2017 Public Lecture held on March 29, 2017 at University of Lagos, Akoka, Lagos, Nigeria, 1-14.

Okoligwe, N. E. and Okezie, A. I. (2014). Relationship between Electricity Consumption and Economic Growth: Evidence from Nigeria (1971-2012). Academic Journal of Interdisciplinary Studies, MCSER Publishing, Rome-Italy, 3(5), 137-152.

Okundamiya, M. S. and Omorogiuwa, O. (2015). Viability of a Photovoltaic-Diesel-Battery Hybrid Power System in Nigeria. Iranica Journal of Energy and Environment, 6(1), 5-12. https://doi.org/10.5829/idosi.ijee.2015.06.01.03

Oladeji, A. S. and Sule, B. F. (2015). Electrical Load Survey and Forecast for a Decentralized Hybrid Power System at Elebu, Kwara State, Nigeria. Nigerian Journal of Technology, 34(3), 591-598. https://doi.org/10.4314/njt.v34i3.23 
Olatomiwa, L., Mekhilef, S. and Ohunakin, O. S. (2016). Hybrid renewable power supply for rural health clinics (RHC) in six geo-political zones of Nigeria. Sustainable Energy Technologies and Assessments, 13, 1-12. https://doi.org/10.1016/j.seta.2015.11.001

Olurinde, L. (2015). Renewable Energy in Nigeria: A Final Report Prepared for Embassy of the Republic of Korea. Centre for Renewable Energy Technology, Nigeria, 1-69.

Oseni, M. O. (2011). An analysis of the power sector performance in Nigeria. Renewable and Sustainable Energy Reviews, 15, 4765-4774. https://doi.org/10.1016/j.rser.2011.07.075

Oseni, M. O. (2012). Improving households' access to electricity and energy consumption pattern in Nigeria: Renewable energy alternative. Renewable and Sustainable Energy Reviews, 16, 3967-3974. https://doi.org/10.1016/j.rser.2012.03.010

Osueke, C. O. and Ezeh, C. T. (2011). Assessment of Nigeria power sub-sector and electricity generation projections. International Journal of Scientific \& Engineering Research, 2(11), 1-7.

Otuna, J. A., Onemano, J. A. and Alayande, A. W. (2012). Assessment of the Hydropower Potential of Kangimi Reservoir in Kaduna State Nigeria. Nigerian Journal of Technology (NIJOTECH), 31(3), 300-307.

Oyedepo, S. O. and Fagbenle R. O. (2011). A Study of Implementation of Preventive Maintenance Programme in Nigeria Power Industry_Egbin Thermal Power Plant, Case Study. Energy and Power Engineering, 3, 207-220. https:// doi.org/10.4236/epe.2011.33027 https:// doi.org/10.1186/2251-6832-3-7

Oyedepo, S. O., Adaramola, M. S. and Paul, S. S. (2012). Analysis of wind speed data and wind energy potential in three selected locations in south-east Nigeria. International Journal of Energy and Environmental Engineering, 3(7), 111. Available at: http://www.journal-ijeee.com/content/3/1/7 https:// doi.org/10.1186/2192-0567-2-15

Oyedepo, S. O. (2012a). Energy and sustainable development in Nigeria: the way forward. Energy, Sustainability and Society, 2(15), 1-17. Available at: http://www.energsustainsoc.com/content/2/1/15

Oyedepo, S. O. (2012b). On energy for sustainable development in Nigeria. Renewable and Sustainable Energy Reviews, 16, 2583- 2598. https:// doi.org/10.1016/j.rser.2012.02.010

Oyedepo, S. O. (2013). Energy in Perspective of Sustainable Development in Nigeria. Sustainable Energy, 1(2), 14 25.

Oyedepo, S. O. (2014a). Towards achieving energy for sustainable development in Nigeria. Renewable and Sustainable Energy Reviews, 34, 255-272. https:/ / doi.org/10.1016/j.rser.2014.03.019

Oyedepo, S. O. (2014b). Development of Small Hydropower: A Pathway towards Achieving Sustainable Energy Development, In: Rupert, C.E (Ed.) Hydropower Types, Development Strategies and Environmental Impacts, Nova Science Publishers, Inc., New York: 67-119.

Oyedepo, S. O., Fagbenle, R. O., Adefila, S. S. and Adavbiele, S. A. (2014). Performance evaluation and economic analysis of a gas turbine power plant in Nigeria. Energy Conversion and Management, 79, 431-440. https://doi.org/10.1016/j.enconman.2013.12.034

Painuly, J. P. (2001). Barriers to Renewable Energy Penetration: A Framework for Analysis. Renewable Energy, 24, 73-89. https://doi.org/10.1016/S0960-1481(00)00186-5

Pereira, E. G., Da Silva, J. N., De Oliveira, J. L. and Machado, C. S. (2012). Sustainable energy: A review of gasification technologies. Renewable Sustainable Energy Review, 16, 4753-4762. https://doi.org/10.1016/j.rser.2012.04.023

Renewable Energy Master Plan. (2006).

Sambo, A. S. (2008). Matching Electricity Supply with Demand in Nigeria. International Association for Energy Economics, $4^{\text {th }}$ Quarter, $32-36$.

Sambo, A. S. (2018), Energy Crisis in Nigeria: Engineers' Proactive Steps towards Energy Self-Sufficiency. Lecture as the First in the Series of the Distinguished Lectures in honour of Engr. Dr. E. J. S. Uujamban, at the University of Benin, Benin City, on the 6th Day of April, 2018, 1-27.

Shaaban, M. and Petinrin, J. O. (2014). Renewable energy potentials in Nigeria: Meeting rural energy needs. Renewable and Sustainable Energy Reviews, 29, 72-84. https://doi.org/10.1016/j.rser.2013.08.078

Siddaiah, R. and Saini, R. P. (2016). A Review on Planning, Configurations, Modeling and Optimization Techniques of Hybrid Renewable Energy Systems for off Grid Applications.

Simonyan, K. J. and Fasina, O. (2013). Biomass resources and bioenergy potentials in Nigeria. African Journal of Agricultural Research, 8(40), 4975-89.

Sustainable Energy for All Initiative (SE4ALL). (2012). In Support of the Objective to Acbieve Universal Access to Modern Energy Services by 2030. Technical Report of Task Force 1: New York. http:/ / www.sustainableenergyforall.org/about-us.

Twidell, J. and Weir, T. (2015). Renewable Energy Resources (3 $3^{\text {rd }}$ Ed.), Routledge, Taylor \& Francis Group, 711 Third Avenue, New York, NY 10017.

Usman, Z. G. and Abbasoglu, S. (2015). An Overview of Power Sector Laws, Policies and Reforms in Nigeria. Asian Transactions on Engineering, 4(2), 6-12. 
Udoudoh, F. P. and Umoren, V. E. (2015). An Appraisal of Public Electricity Performance and its Implications on Economic Development in Nigeria. Sacha Journal of Environmental Studies, 5(1), 63-73.

United Nations. (2006). The millennium development goals report, United Nations, New York.

Vincent-Akpu, I. (2012). Renewable Energy Potentials in Nigeria. IALA12 Conference Proceedings Energy Future The Role of Impact Assessment, 32nd Annual Meeting of the International Association for Impact Assessment, 27 May-1 June 2012, Porto-Portugal.

WADE. (2009). More for Less: How Decentralised Energy Can Deliver Cleaner, Cheaper and More Efficient Energy in Nigeria, ICEED. Available at: http:/ / www.localpower.org

Wei-Ming, C., Hana, K. and Hideka, Y. (2014). Renewable energy in eastern Asia: Renewable energy policy review and comparative SWOT analysis for promoting renewable energy in Japan, South Korea, and Taiwan. Energy Policy, 74, 319-329. https://doi.org/10.1016/j.enpol.2014.08.019

Werner, D. and Faruk, Y. Y. (2015). An Overview with a Special Emphasis on Renewable Energy, Energy Efficiency and Rural Electrification. $2^{\text {nd }}$ Edition, June 2015, Nigerian Energy Support Programme (NESP), Federal Secretariat Complex Shehu Shagari Way, Maitama, Abuja, Nigeria, 1-152.

World Bank. (1991). World Development Report: The Challenge of Development. Oxford University Press. World Bank, New York (https://openknowledge.worldbank.org/handle/10986/5974 License: CC BY 3.0 IGO).

World Bank. (2013). Low-Carbon Development Opportunities for Nigeria, Raffaello Cervigni, John Allen Rogers, and Max Henrion, (eds.), (International Bank for Reconstruction and Development/The World Bank, Washington, 2013), Washington, USA.

World Bank. (2014). World Development Indicators. Available at: http://data.worldbank.org/products/wdi

Zubairu, G. U., Serkan, A., Neyre, T. E. and Murat, F. (2015). Transforming the Nigerian Power Sector for Sustainable Development. Energy Policy, 87, 429-437. https://doi.org/10.1016/j.enpol.2015.09.004 